\title{
Genetic diversity and genomic resources available for the small millet crops to accelerate a New Green Revolution
}

\author{
Travis L. Goron and Manish N. Raizada * \\ Department of Plant Agriculture, University of Guelph, Guelph, ON, Canada
}

Small millets are nutrient-rich food sources traditionally grown and consumed by subsistence farmers in Asia and Africa. They include finger millet (Eleusine coracana), foxtail millet (Setaria italica), kodo millet (Paspalum scrobiculatum), proso millet (Panicum miliaceum), barnyard millet (Echinochloa spp.), and little millet (Panicum sumatrense). Local farmers value the small millets for their nutritional and health benefits, tolerance to

OPEN ACCESS

Edited by:

Joanna Marie-France Cross,

Inonu University, Turkey

Reviewed by:

Dayong Li,

Chinese Academy of Sciences, China

Velu Govindan

CIMMYT, Mexico

Anil Kumar

G B Pant University of Agriculture and

Technology, India

*Correspondence:

Manish N. Raizada,

Department of Plant Agriculture,

University of Guelph, 50 Stone Road

East, Guelph, ON N1G 2W1, Canada

raizada@uogue/ph.ca

Specialty section:

This article was submitted to Plant Genetics and Genomics, a section of the journal Frontiers in Plant Science

Received: 21 December 2014

Accepted: 27 February 2015

Published: 24 March 2015

Citation:

Goron TL and Raizada MN (2015)

Genetic diversity and genomic

resources available for the small millet

crops to accelerate a New Green

Revolution. Front. Plant Sci. 6:157.

doi: 10.3389/fpls.2015.00157 extreme stress including drought, and ability to grow under low nutrient input conditions, ideal in an era of climate change and steadily depleting natural resources. Little scientific attention has been paid to these crops, hence they have been termed "orphan cereals." Despite this challenge, an advantageous quality of the small millets is that they continue to be grown in remote regions of the world which has preserved their biodiversity, providing breeders with unique alleles for crop improvement. The purpose of this review, first, is to highlight the diverse traits of each small millet species that are valued by farmers and consumers which hold potential for selection, improvement or mechanistic study. For each species, the germplasm, genetic and genomic resources available will then be described as potential tools to exploit this biodiversity. The review will conclude with noting current trends and gaps in the literature and make recommendations on how to better preserve and utilize diversity within these species to accelerate a New Green Revolution for subsistence farmers in Asia and Africa.

Keywords: finger millet, kodo millet, foxtail millet, barnyard millet, proso millet, little millet, New Green Revolution, biodiversity

\section{Small Millets -Valuable Crops Neglected by the Green Revolution}

The "Green Revolution" represents a period of massive agricultural advancement, and is often credited with saving over a billion people from starvation in the developing world (Borlaug, 2000; Evenson and Gollin, 2003). The initial focus of the Revolution was the promotion of semi-dwarf varieties of major cereal grain crops especially rice, wheat, and maize. Such modern varieties were also methodically bred to deal with environmental stresses, and in many cases produced yields several times higher than local cultivars. A highly cited example is the global success of "miracle rice" in the 1960s (De Datta et al., 1968). When faced with potential mass famine, the

Abbreviations: EST, expressed-sequence tag; RFLP, restriction fragment length polymorphism; AFLP, amplified fragment length polymorphism; SSR, simple sequence repeat; WUE, water use efficiency; NUE, nitrogen use efficiency. 
Punjab region of India collaborated with international advisors to introduce IR8, a semi-dwarf rice modern variety. IR8 was found to produce up to 10 times the yield of traditionally grown varieties (De Datta et al., 1968) and helped to transform India's food production from deficit to surplus; national rice production tripled accompanied by a dramatic drop in price. IR 8 and its progenitors as well as other modern varieties of cereals were further exported to other regions of the world with similar results especially in Latin America and Asia (Evenson and Gollin, 2003).

However, there are regions of the world that did not experience a Green Revolution. Sub-Saharan Africa experienced a lag in the benefits of modern varieties although efforts were made for their introduction and establishment (Ejeta, 2010). Reasons for the failure are complex. Many commentators point to institutional and political difficulties that may have hindered dissemination of new technology (Ejeta, 2010). However, it is also important to consider the agroeconomic complexities of the region, where a mixture of species less common elsewhere in the world are traditionally grown (Evenson and Gollin, 2003). A wide range of climatic zones and unique farming practices with a spectrum of soil types also created a challenge. In the early part of the Green Revolution, breeding generally consisted of modifying pre-existing genetic resources of wheat, maize, and rice in which research had already been conducted by developed nations. These varieties would be further bred to incorporate additional traits to increase yields. The strategy was not applicable to many African crops where essentially no formal work existed for researchers to build upon. In fact, it has been suggested that some African farmers faced increased hardship in response to the Green Revolution as a result of a global drop in food prices caused by its massive success elsewhere (Evenson and Gollin, 2003).

More optimistically, in the later years of the Green Revolution, research broadened to include less common food crops and began to close the gap in yield increases due to modern varieties. Locally administered organizations, such as the International Crops Research Institute for the Semi-Arid Tropics (ICRISAT), established research programs that included farmers in the dialog to strategically build a bank of genetic resources for traditionally grown species better suited to local climates and cropping systems. One group of such species is collectively known as the small millets and includes six cereal crops: finger millet (Eleusine coracana), foxtail millet (Setaria italica), kodo millet (Paspalum scrobiculatum), proso millet (Panicum miliaceum), barnyard millet (Echinochloa spp.), and little millet (Panicum sumatrense). Though all six cereals share a similar superficial classification (small grained cereals), they differ vastly in their phylogenies and continue to be grown in some of the most remote farms on Earth - thus isolation has maintained a wealth of agricultural and functional diversity. Their uses vary from animal fodder to human consumption, in which the small seeds can be ground into flour, cooked as porridge, or alternately fermented into enriched foods or alcoholic products. Where they are traditionally grown (Figure 1), small millets are highly valued for their diverse benefits and in many instances are considered nutritionally superior to other carbohydrate sources like rice and wheat (Hegde et al., 2005). Additionally, many of the small millets require very little fertilizer input as compared to more

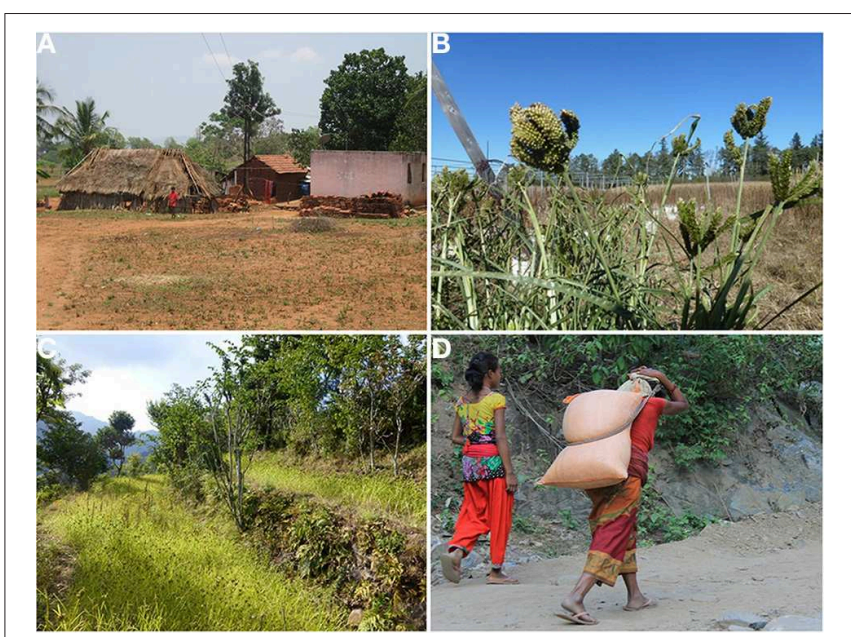

FIGURE 1 | Depictions of small millet cultivation. (A) A typical subsistence small millet farm in India where the crops are grown under low input conditions and valued for their high stress tolerance. Source: M. Raizada. (B) Finger millet seed heads nearing maturity at the University of Guelph in Canada. The seed heads resemble the fingers of a human hand. Source: T. Goron. (C) Finger millet growing in a terraced field on a smallholder farm in Nepal. Source: M. Raizada. (D) Drudgery associated with transporting grain in the rural areas of Nepal. Source: M. Thilakarathna.

intensive grain cropping monocultures. Many reports also exist regarding their high degree of pest resistance and long-term storability, both traits which make the cultivation of small millets good insurance against famine and crop failure (Tsehaye et al., 2006; Reddy et al., 2011).

Although previously neglected, the value of small millets in modern agricultural stability has begun to be identified. Much work has been accomplished toward the development of modern varieties with the goal of better directing existing diversity toward agricultural challenges of the new millennium. The purpose of this review is to highlight the diverse traits of each crop that are valued by farmers and consumers (e.g., nutritional quality) that have potential for selection, improvement or mechanistic study, along with other phenotypes of interest, then to describe the germplasm, genetic and genomic resources available as potential tools to exploit this biodiversity. The review will conclude with noting current trends and gaps in the literature and make recommendations on how to better preserve and utilize diversity within these species to accelerate a New Green Revolution.

\section{Diversity of the Small Millets}

\section{Finger Millet (Eleusine coracana)}

Finger millet was domesticated in western Uganda and the Ethiopian highlands (Figure 2) at least 5000 years ago before introduction to India approximately 3000 years ago (Dida et al., 2008). It is called finger millet, because the inflorescence resembles the fingers of a human hand (Figure 1). The morphology of the inflorescence can be used to differentiate between the two subspecies, africana and coracana (Dida and Devos, 2006). Each subspecies can be further divided into several races. Finger millet 
is an allotetraploid. Genomic donors of the "A" genome are most likely Eleusine indica and Eleusine trisachya (Liu et al., 2014). The " $\mathrm{B}$ " genome has yet to be uncovered, and may have been contributed by an extinct ancestor (Liu et al., 2014). It is cultivated on 1.8 million ha in India, and also fills a substantial niche in eastern Africa (Table 1) (Dida and Devos, 2006). Kenyan farmers receive a high price for the grain, often twice that of maize and sorghum (Dida and Devos, 2006). The crop is highly valued in part due to its nutritional content, being especially calcium rich. Finger millet also contains methionine and tryptophan, amino acids which are often absent in starch-based diets of some subsistence farmers (Bhatt et al., 2011). Health benefits have been investigated, including anti-cancer and anti-diabetic activity, arising, respectively, from the grain's polyphenol content (anti-oxidant activity) and high fiber (which promotes slow digestion and hence stability of blood sugar) (Chandrasekara and Shahidi, 2011a; Devi et al., 2014). The species will produce 5 tons/ha under optimum conditions (Dida and Devos, 2006) and requires very little nitrogen fertilization, with some reports indicating the most economic rate of application may be between 20 and $60 \mathrm{~kg} / \mathrm{ha} \mathrm{(Hegde} \mathrm{and}$ Gowda, 1986; Pradhan et al., 2011). The plant is highly tolerant to drought and salt stress, though a wide diversity of stress resistance has been reported across genotypes (Uma et al., 1995; Bhatt et al., 2011). Unlike many crops consumed by subsistence farmers, finger millet has maintained high socio-economic importance in the Indian and African semi-arid tropics (Benin et al., 2004; Gull et al., 2014) and has received a level of investigation unattained by some of its cousins.

ICRISAT conserves 6804 finger millet germplasm accessions originating from 25 different countries. Other organizations
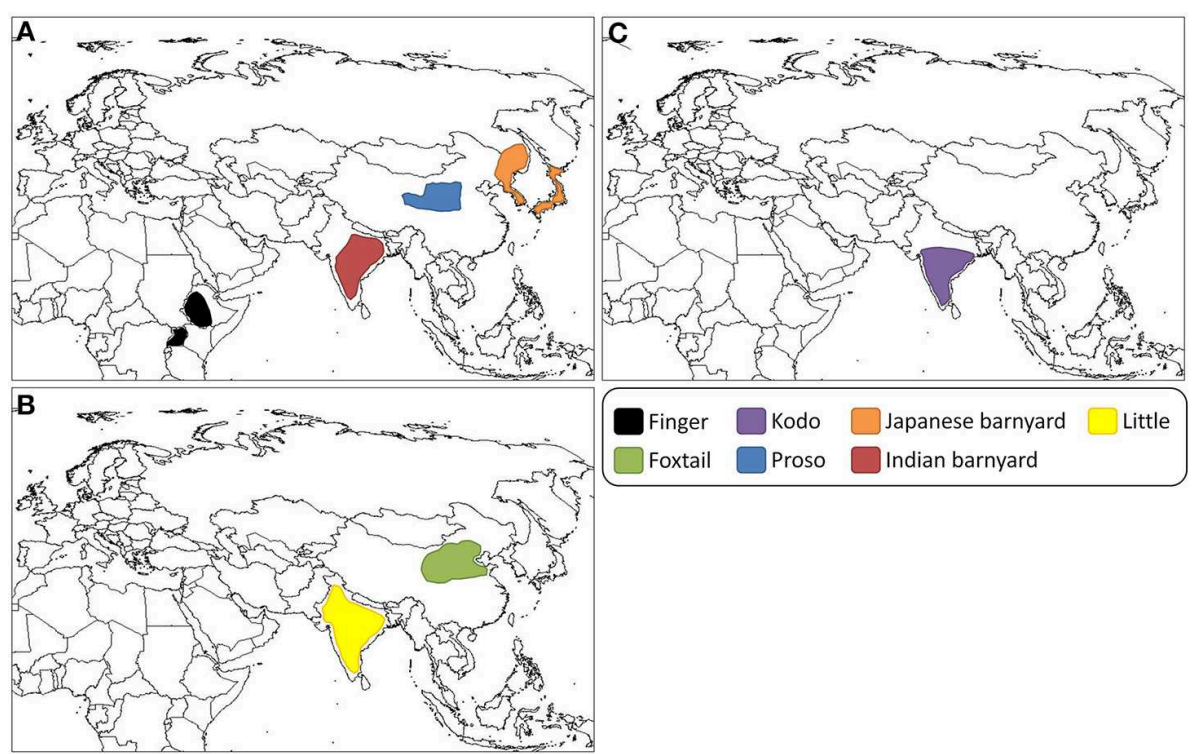

FIGURE 2 | Predicted geographic centers of domestication of the small millets. (A) Finger millet is predicted to have been domesticated in Uganda and the Ethiopian Highlands (Dida et al., 2008). Proso millet was likely domesticated on the Loess Plateau, China (M'Ribu and Hilu, 1994; Hu et al., 2008, 2009). Japanese barnyard millet was likely domesticated in Japan or Eastern Asia (Yabuno, 1962). It has been suggested that Indian barnyard millet was domesticated at multiple sites across its current cultivation range in India (de Wet et al., 1983c). (B) Predicted sites of domestication of foxtail millet and little millet, respectively, on the North China Plain (Yang et al., 2012) and in India (de Wet et al., 1983a). (C) Kodo millet may have been domesticated at multiple sites across its current range of cultivation in India (de Wet et al., 1983b).

TABLE 1 | Areas where small millets are cultivated in significant quantities for human consumption.

\begin{tabular}{|c|c|c|c|}
\hline Common name & Species name & Regions of cultivation & References \\
\hline Finger millet & Eleusine coracana & $\begin{array}{l}\text { India, Nepal, China, Myanmar, Sri Lanka, Kenya, Uganda, Eritrea, } \\
\text { Sudan, Zimbabwe, Zambia, Malawi, Madagascar, Rwanda, Burundi }\end{array}$ & Dwivedi et al., 2012 \\
\hline Foxtail millet & Setaria italica & China (dry northern regions), India, Nepal, Korea, Japan & Dwivedi et al., 2012 \\
\hline Kodo millet & Paspalum scrobiculatum & India & Dwivedi et al., 2012 \\
\hline Proso millet & Panicum miliaceum & $\begin{array}{l}\text { India, China, Nepal, western Myanmar, Sri Lanka, Pakistan, and } \\
\text { South East Asian countries }\end{array}$ & $\begin{array}{l}\text { Hu et al., 2008; } \\
\text { Nirmalakumari et al., } 2008\end{array}$ \\
\hline Japanese barnyard millet & Echinochloa esculenta & Japan, Korea, Northeastern China & Yabuno, 1987 \\
\hline Indian barnyard millet & Echinochloa frumentacea & Pakistan, India, Nepal, and central Africa & Yabuno, 1987 \\
\hline Little millet & Panicum sumatrense & $\begin{array}{l}\text { India, Sri Lanka, Pakistan, Myanmar, and other South East Asian } \\
\text { countries }\end{array}$ & Hiremath et al., 1990 \\
\hline
\end{tabular}


manage germplasm banks of their own, the largest of which are summarized in Table 2. From these large collections, ICRISAT and other institutions group all genotypes according to region of origin or other parameters (Brown, 1989; Diwan et al., 1995; Hu et al., 2000; Wang et al., 2007). A subset of each group is selected that is representative of the genetic diversity of the crop: this group is termed the "core collection" and typically consists of $\sim 10 \%$ of all available accessions. Core collections facilitate breeding by providing an efficient means to screen for desired traits from a large pool of genotypes. Mini-core collections, that represent $\sim 1 \%$ of the total accessions, can be used by these institutions to further streamline the available genetic diversity.

The morphological diversity present within finger millet is immense. For example, a range of seed colors can be produced which are correlated with protein and calcium content (Vadivoo et al., 1998). Landraces with different attributes (e.g., time to maturity, bird tolerance, drought tolerance, disease tolerance) are valued by farmers based on local agricultural complexities that reflect their productivity across multiple agroeconomic zones (Tsehaye et al., 2006). For example, in the Ethiopian highlands, three high-yield landraces were identified and further developed into the commercial lines Tadesse, Padet, and Boneya (Aduguna, 2007). During a severe drought, Tadesse finger millet was the only cereal that remained productive. Farmers received double the price for the grain as compared to maize (Aduguna, 2007). This study illustrates what can be accomplished if germplasm banks are properly utilized for the selection of desirable traits.

The degree of morphological differences in finger millet requires that even core collections to be quite large; specialized tools will be needed to simplify characterization of functional diversity. Molecular markers represent one class of such tools, including restriction fragment length polymorphisms (RFLP), amplified fragment length polymorphisms (AFLP), expressedsequenced tags (EST), and simple sequence repeats (SSR). Very few are reported for finger millet but more are beginning to appear in the literature. Molecular markers have been utilized in attempts to characterize calcium dynamics (Yadav et al., 2014b), disease resistance (Babu et al., 2014d), and in the association mapping of various agronomic traits as well as tryptophan accumulation (Babu et al., 2014a,b). Marker-assisted research has suggested that there was little sequence diversity in finger millet populations (Muza et al., 1995; Salimath et al., 1995; Yadav et al., 2014b), but this would be surprising given the geographic diversity in which finger millet is grown. Molecular markers have enabled linkage maps of the genome to be assembled (Dida et al., 2007). While progress has recently increased, the availability of a published genomic sequence would accelerate the development of markers to assist with genotype classification and breeding. In March 2014, the Bio-resources Innovations Network for Eastern Africa Development (Bio-Innovate) announced a finger millet sequencing project (Table 3); the initial genome assembly has been completed and the full sequence is expected by the end of $2014^{1}$.

\footnotetext{
${ }^{1}$ http://bioinnovate-africa.org / about-us / news / item / 162-finger-millet-genomicsproject-to-provide-researchers-with-better-tools-for-variety-production
}

Research illuminating the finger millet transcriptome is beginning to appear. As the crop is valued for its high calcium content, studies have characterized calcium sensing and accumulation mechanisms across genotypes differing in their grain calcium content with the use of transcriptome high-throughput sequencing (Kumar et al., 2014b; Singh et al., 2014). A similar transcriptome analysis has been conducted on salinity responsiveness (Rahman et al., 2014). To investigate mechanisms behind the crop's impressively high nitrogen utilization efficiency (NUE), the behavior of transcription factors Dof1 and Dof2 have been analyzed. It was found that in the roots of a high-protein variety, the EcDof1/EcDof2 ratio was greater than that of a low protein variety, indicating a higher activation of $\mathrm{N}$ uptake and assimilation genes (Gupta et al., 2014a). The authors suggest that this ratio may in the future be utilized to screen other genotypes for high NUE.

Homologs of genes known to be agronomically important in major cereals, such as the transcripts described above, may assist with targeted breeding efforts in crops that are less characterized. Specifically, sequence variants of these genes may be used to develop orthologous molecular markers; those variants that correlate with desired traits may be used to screen accessions and subsequently assist in marker-assisted breeding efforts. This strategy may represent a way forward in the small millets. For example, finger millet researchers have isolated orthologs of genes known to be involved in grain amino acid composition (Opaque 2) and calcium content (calcium transporters, calmodulin) (Reddy et al., 2011; Nirgude et al., 2014). The researchers then associated SSR polymorphisms within these genes to characterize accessions that differed in their protein and calcium content, thus creating a targeted, cost-effective crop improvement strategy. A similar strategy to improve finger millet seed calcium content was also reported independently that focused on orthologs of calcium-binding proteins (CBPs) with extensive characterization of a seed dominant calmodulin (Kumar et al., $2014 a, c)$. A parallel strategy has been suggested for disease resistance in finger millet based on the initial isolation of disease resistance receptors (Reddy et al., 2011; Babu et al., 2014c).

Progress has also occurred with respect to transgenic protocols for finger millet utilizing Agrobacterium and callus cell bombardment (Kothari et al., 2005; Ceasar and Ignacimuthu, 2009, 2011; Sharma et al., 2011; Jagga-Chugh et al., 2012; Plaza-Wüthrich and Tadele, 2012). Such techniques have allowed finger millet plants to be improved for drought and salinity tolerance (Ramegowda et al., 2012; Anjaneyulu et al., 2014; Hema et al., 2014), zinc accumulation (Cakmak, 2008; Ramegowda et al., 2013), and disease resistance (Latha et al., 2005).

\section{Foxtail Millet (Setaria italica)}

Named for the bushy, tail-like appearance of its immature panicles, foxtail millet has received a promising amount of research attention. Domesticated in China (Figure 2) approximately 8700 years ago, foxtail millet is considered one of the world's oldest crops and ranks second in total world millet production, providing six million tons of grain for people throughout areas in southern Europe and Asia (Li and Wu, 1996; Yang et al., 2012). It is one of the main food crops in regions of the dry north of 
TABLE 2 | Significant germplasm collections of the small millets.

\begin{tabular}{|c|c|c|c|}
\hline Common name & Institution & Headquarters & Number of accessions \\
\hline \multirow[t]{8}{*}{ Finger millet } & - National Bureau of Plant Genetic Resources (NBPGR) & New Delhi, India & 9522 (Dwivedi et al., 2012) \\
\hline & - International Crops Research Institute for the Semi-Arid Tropics (ICRISAT) & Patancheru, India & $6804^{\mathrm{a}}$ \\
\hline & - Kenya Agricultural Research Institute (KARI) & Muguga, Kenya & 2875 (Dwivedi et al., 2012) \\
\hline & - Institute of Biodiversity Conservation (IBC) & $\begin{array}{l}\text { Addis Ababa, } \\
\text { Ethiopia }\end{array}$ & 2156 (Dwivedi et al., 2012) \\
\hline & - Serere Agricultural and Animal Production Research Institute (SAARI) & Soroti, Uganda & 1231 (Dwivedi et al., 2012) \\
\hline & - SADC Plant Genetic Resource Centre & Lusaka, Zambia & 1037 (Dwivedi et al., 2012) \\
\hline & $\begin{array}{l}\text { - Central Plant Breeding and Biotechnology Division, Nepal Agricultural } \\
\text { Research Council (CPBBD) }\end{array}$ & Kathmandu, Nepal & 869 (Dwivedi et al., 2012) \\
\hline & - National Center for Genetic Resources Preservation & Fort Collins, USA & 702 (Dwivedi et al., 2012) \\
\hline \multirow[t]{8}{*}{ Foxtail millet } & - Chinese National Genebank (CNGB) & Shenzhen, China & 26,670 (Wang et al., 2012) \\
\hline & - National Bureau of Plant Genetic Resources (NBPGR) & New Delhi, India & 4330 (Dwivedi et al., 2012) \\
\hline & • ORSTOM-MONTP & Montpellier, France & 3500 (Dwivedi et al., 2012) \\
\hline & - All India Coordinated Minor Millet Project (AICMMP) & Bangalore, India & 2512 (Dwivedi et al., 2012) \\
\hline & - International Crops Research Institute for the Semi-Arid Tropics (ICRISAT) & Patancheru, India & $1535^{\mathrm{C}}$ \\
\hline & - National Institute of Agrobiological Sciences (NIAS) & Kannondai, Japan & $1299^{d}$ \\
\hline & - North Central Regional Plant Introduction Station, USDA-ARS & Ames, USA & 1000 (Dwivedi et al., 2012) \\
\hline & • Biologie Végétale Appliquée, Institut Louis Pasteur (IUT) & $\begin{array}{l}\text { l'Argonne- } \\
\text { Strasbourg, } \\
\text { France }\end{array}$ & 850 (Dwivedi et al., 2012) \\
\hline Kodo millet & - USDA Agricultural Research Service (USDA-ARS) & Griffin, USA & $336^{f}$ \\
\hline \multirow[t]{10}{*}{ Proso millet } & - N.I. Vavilov All-Russian Scientific Research Institute of Plant Industry & $\begin{array}{l}\text { St. Petersburg, } \\
\text { Russian } \\
\text { Federation }\end{array}$ & 8778 (Dwivedi et al., 2012) \\
\hline & $\begin{array}{l}\text { - Institute of Crop Germplasm Resources, Chinese Academy of Agricultural } \\
\text { Sciences (ICGR-CAAS) }\end{array}$ & Beijing, China & 6517 (Dwivedi et al., 2012) \\
\hline & - Ustymivka Experimental Station of Plant Production & $\begin{array}{l}\text { S. Ustymivka, } \\
\text { Ukraine }\end{array}$ & 3976 (Dwivedi et al., 2012) \\
\hline & - Yuryev Plant Production Institute UAAS & Kharkiv, Ukraine & 1046 (Dwivedi et al., 2012) \\
\hline & - International Crops Research Institute for the Semi-Arid Tropics (ICRISAT) & Patancheru, India & $842^{9}$ \\
\hline & - Botanical Garden of the Plant Breeding and Acclimatization Institute & $\begin{array}{l}\text { Bydgoszcz, } \\
\text { Poland }\end{array}$ & 721 (Dwivedi et al., 2012) \\
\hline & - USDA Agricultural Research Service (USDA-ARS) & Griffin, USA & $719^{h}$ \\
\hline & - North Central Reg. Plant Introd. Station, USDA-ARS & Ames, USA & 713 (Dwivedi et al., 2012) \\
\hline & - Estación de Iguala, Instituto Nacional de Investigaciones Agrícolas (INIA) & Iguala, Mexico & 400 (Dwivedi et al., 2012) \\
\hline & - National Institute of Agrobiological Sciences (NIAS) & Kannondai, Japan & $302^{i}$ \\
\hline
\end{tabular}


TABLE 2 | Continued

\begin{tabular}{|c|c|c|c|}
\hline Common name & Institution & Headquarters & Number of accessions \\
\hline Barnyard millet (both species) & - International Crops Research Institute for the Semi-Arid Tropics (ICRISAT) & Patancheru, India & $743^{j}$ \\
\hline Japanese barnyard millet & - National Institute of Agrobiological Sciences (NIAS) & Kannondai, Japan & $159^{k}$ \\
\hline Indian barnyard millet & - USDA Agricultural Research Service (USDA-ARS) & Griffin, USA & $232^{1}$ \\
\hline \multirow[t]{3}{*}{ Little millet } & - All India Coordinated Minor Millet Project (AICMMP) & Bangalore, India & 544 (Dwivedi et al., 2012) \\
\hline & - International Crops Research Institute for the Semi-Arid Tropics (ICRISAT) & Patancheru, India & $466^{\mathrm{m}}$ \\
\hline & - USDA Agricultural Research Service (USDA-ARS) & Griffin, USA & $212^{n}$ \\
\hline
\end{tabular}

${ }^{a}$ http://www.icrisat.org/crop-fingermillet.htm

${ }^{b}$ http://www.ars-grin.gov/npgs/index.html

${ }^{c}$ http://www.icrisat.org/crop-foxtailmillet.htm

${ }^{d}$ http://www.gene.affrc.go.jp/index_en.php

${ }^{\mathrm{e}} \mathrm{http}: / /$ www.ars-grin.gov/npgs/index.html

${ }^{f}$ http://www.ars-grin.gov/npgs/index.html

ghttp://www.icrisat.org/crop-prosomillet.htm

${ }^{h}$ http://www.ars-grin.gov/npgs/index.html

inttp://www.gene.affrc.go.jp/index_en.php

${ }^{j}$ http://www.icrisat.org/crop-barnyardmillet.htm

${ }^{k}$ http://www.gene.affrc.go.jp/index_en.php

' http://www.ars-grin.gov/npgs/index.html

${ }^{m}$ http://www.icrisat.org/crop-littlemillet.htm

${ }^{n}$ http://www.ars-grin.gov/npgs/index.html

TABLE 3 | Small millet genomic resources and features.

\begin{tabular}{|c|c|c|c|c|c|}
\hline Common name & Ploidy & Chromosome number & $\begin{array}{l}\text { Genome size estimate (pg, } \\
\text { 2C) }\end{array}$ & $\begin{array}{l}\text { ESTs available from } \\
\mathrm{NCB}^{\mathrm{a}}\end{array}$ & $\begin{array}{l}\text { Genome sequence } \\
\text { availability }\end{array}$ \\
\hline Finger millet & Tetraploid & $\begin{array}{l}2 n=4 x=36 \text { (Bisht and Mukai, } \\
\text { 2001) }\end{array}$ & $\begin{array}{l}\text { 3.34-3.87 (Mysore and Baird, } \\
\text { 1997) }\end{array}$ & 1982 & Sequencing in progress ${ }^{b}$ \\
\hline Foxtail millet & Diploid & $2 n=2 x=18$ (Wanous, 1990) & $\begin{array}{l}\text { 1.02-1.04 (D'Ennequin et al., } \\
\text { 1998) }\end{array}$ & 66,051 & $\begin{array}{l}\text { Two reference genomes } \\
\text { (Bennetzen et al., 2012; } \\
\text { Zhang et al., 2012) }\end{array}$ \\
\hline Proso millet & Tetraploid & $\begin{array}{l}2 n=4 x=36 \text { (Baltensperger, } \\
1996)\end{array}$ & 2.08 (Kubešová et al., 2010) & 211 & $\mathrm{~N} / \mathrm{A}$ \\
\hline $\begin{array}{l}\text { Japanese barnyard } \\
\text { millet }\end{array}$ & Hexaploid & $\begin{array}{l}2 n=6 x=36 \text { (de Wet et al. } \\
1983 c)\end{array}$ & N/A & $\begin{array}{l}0 \text { (74 in closely-related } \\
\text { Echinochloa crus-galli) }\end{array}$ & N/A \\
\hline Indian barnyard millet & Hexaploid & $2 n=6 x=36$ (Wanous, 1990) & 2.7 (Abrahamson et al., 1973) & 0 & N/A \\
\hline Little millet & Tetraploid & $2 n=4 x=36$ (Wanous, 1990) & N/A & 0 & N/A \\
\hline
\end{tabular}

${ }^{a}$ http://www.ncbi.nlm.nih.gov/ ${ }^{b}$ http:///bioinnovate-africa. org/about-us/news/item/162-finger-millet-genomics-project-to-provide-researchers-with-better-tools-for-variety-production

China (Wang et al., 2012). Foxtail millet is cultivated to a limited extent in North America for silage, birdseed, and as a cover crop. It is quick to mature, able to produce seed in 75-90 days, and sometimes grown as a "catch-crop" in between the plantings of other species (Baltensperger, 2002). Herbicide-resistant lines of foxtail millet have been identified and studied in detail (Zhu et al., 2006). Additionally, the plant is quite drought resistant and tolerant to salt stress (Jayaraman et al., 2008). The cultivar "Prasad" has been identified as being particularly salt-tolerant, perhaps due to an effective antioxidant mechanism mediated by polyamine accumulation (Sudhakar et al., 2015).

As opposed to finger millet which was the result of a single domestication event (Dida et al., 2008), the history of foxtail millet is more complex. Sequence diversity of 250 Chinese genotypes was found to be quite high, averaging 20.9 alleles per locus when examined with 77 SSRs (Wang et al., 2012). Alleles clustered into two main geographic diversity centers, indicating the possibility of two domestication events within China; more work is needed to confirm this hypothesis (Wang et al., 2012). Additionally, it has been suggested that foxtail millet was independently domesticated in Europe based on archeological evidence (Jusuf and Pernes, 1985; Hunt et al., 2008; Hirano et al., 2011).

Foxtail millet is closely related to the hardy weed Setaria viridis, which is assumed to be its progenitor. S. viridis, or green foxtail, often exists in close proximity to its cultivated cousin and is problematic throughout Eurasia and North America with many reports of herbicide resistance (Morrison et al., 1989; Marles et al., 1993; Heap, 1997). Some evidence suggests genetic clustering across foxtail species is dictated primarily by region and not taxonomy, implying that interspecific hybridization between 
S. viridis and modern S. italica is common (Li et al., 1942; Jusuf and Pernes, 1985). Indeed, deliberate crosses between these species have resulted in resistance to a variety of herbicides (Darmency and Pernes, 1985, 1989; Wang et al., 1996; Wang and Darmency, 1997). However, agronomic traits in many of the crosses were closer to the weedy variety of Setaria; hybrids displayed seed shedding, spindly shoot tissue, and low yield as well as the fertility losses associated with hybridization. These reports highlight the possibility of using interspecific hybridization to study different agronomically valuable traits from wild millet relatives in a domesticated genetic background for future breeding applications.

After its domestication in China, foxtail millet spread throughout Asia, Europe, and eventually to North America (Jusuf and Pernes, 1985). Its large range has resulted in three different races, each with multiple subraces. Moharia is common in Europe, Russia, and the Middle East. Maxima can be found in Eastern China, Georgia, Japan, Korea, Nepal, northern India, and the USA where it was introduced for the purposes of animal feed. Indica predominates in southern India and Sri Lanka (Table 1) (Jusuf and Pernes, 1985).

An interesting feature of modern foxtail millet diversity is the global distribution of two phenotypically different varietiesthe waxy and non-waxy grain type (Van et al., 2008). Waxiness in cereal grains is caused by lowered levels of amylose in the grain endosperm, which gives the grain a sticky texture when cooked (Van et al., 2008). Geographical occurrence of these two groups of foxtail millet varieties coincides with the ethnological preferences of local human populations. In East and South East Asia, some local communities are known to prefer sticky cereals (e.g., glutinous rice) driven by the use of chopsticks by these cultures-it is in these regions that the waxy millet phenotype can be found (Van et al., 2008). The non-waxy grain phenotype is more widespread, cultivated throughout Eurasia and parts of Africa (Kawase et al., 2005). Control of the phenotype is due to transposable-element (TE) insertion events interrupting amylase production, and foxtail millet has been suggested as a model for studying TE-mediated evolution (Kawase et al., 2005).

Like finger millet, there is an abundance of foxtail millet germplasm available to the scientific community (Table 2). Due to its importance in China, the Chinese National Genebank (CNGB) appears to maintain the largest collection by far, totalling 26,670 accessions as of 2012 (Wang et al., 2012). ICRISAT holds germplasm from 26 countries, and genebanks in Japan (National Institute of Agrobiological Sciences, NIAS) and the USA (USDA, Plant Genetic Resources Conservation Unit, PGRCU) ensure access to a wide range of foxtail millet diversity. Some core and mini-core collections have been assembled (Upadhyaya et al., 2008 , 2011). However, considering the wide range of foxtail millet cultivation and the diversity of accessions, many more core collections should be generated, especially in China ( $\mathrm{Li}$ et al., 1998) to facilitate breeding efforts. Diverse foxtail millet landraces may provide valuable alleles to assist in these breeding efforts. For example, landraces from the north of China are typically well-adapted to cold weather with short growing seasons, and are highly sensitive to light and temperature changes while those from southern regions grow better in high temperatures and humidity (Wang et al., 2012), demonstrating the types of useful alleles that may exist for this crop.

Foxtail millet has enjoyed more genetic characterization than the other small millets. Recently there has been a push to utilize the species as a model system for biofuel grasses. It is closely related to the bioenergy crops switchgrass (Panicum virgatum), napier grass (Pennisetum purpureum), and pearl millet (Pennisetum glaucum) (Doust et al., 2009). Foxtail millet has several characteristics that are valued in a model system-a small genome ( $\sim 490 \mathrm{Mbp})$, small plant size, and a quick generation time, unusual for $\mathrm{C} 4$ grasses. As a result, two full reference sequences have been compiled using genotypes Yugul and Zhang Gu (Bennetzen et al., 2012; Zhang et al., 2012). In these studies, the authors also created high-density linkage maps with another foxtail millet line and green foxtail, and examined the evolution and mechanisms of C4 photosynthesis in detail (Bennetzen et al., 2012; Zhang et al., 2012).

Instigated by the newly available sequence data, research in foxtail millet molecular genomics continues to rapidly progress. Many genetic markers have been reported and utilized in foxtail millet to generate maps, analyze DNA polymorphisms, evolutionary origin(s), and relatedness to other cereals for future crop improvement efforts (Wang et al., 1998; Schontz and Rether, 1999; Jia et al., 2009; Yadav et al., 2014a). A large library of markers consisting of intron-length polymorphisms (ILPs) has been generated, in part enabled by an abundance of EST data which can be used to generate flanking primers (Muthamilarasan et al., 2014). Initial work toward marker-based, high-throughput genotype identification has been accomplished (Gupta et al., 2012; Pandey et al., 2013). For example, an allele-specific single nucleotide polymorphism (SNP) coding for a dehydration responsive element binding (DREB) gene was shown to associate with stress tolerance (Lata et al., 2011). The SNP has potential in marker-assisted breeding selection, and was validated in a foxtail millet core collection in which the allele was found to account for $27 \%$ of total variation of stress-induced lipid peroxidation (Lata and Prasad, 2013). In an association mapping study, eight SSR markers were found to correlate with nine different agronomic traits (Gupta et al., 2014b). ESTs and peptides have been identified which are differentially expressed between salt tolerant and non-tolerant cultivars (Veeranagamallaiah et al., 2008; Puranik et al., 2011). A genome-wide transcriptome has been generated after exposure to drought stress, in which regulatory roles of small interfering RNAs and non-coding RNAs were described (Qi et al., 2013). From this study, 2824 annotated genes were identified with drought-responsive expression patterns. Such comprehensive studies should be extended to other stress pathways for better characterization of available foxtail millet germplasm. The data might also be used to design useful millet microarrays. Using the reference genomes described above, research groups have begun to re-sequence genotypes of foxtail millet and identify vast libraries of SNPs and other markers (Bai et al., 2013; Jia et al., 2013). This information has been used to classify landraces according to flowering time, yield attributes, waxy character, and other agronomically important traits (Jia et al., 2013; Bai et al., 2013). The re-sequencing of diverse foxtail millet germplasm should continue as a strategy to aid marker-assisted breeding 
efforts. Much work has also been accomplished in the behavior of transcription factors in foxtail millet under a variety of stressful conditions, details of which have been conveniently compiled in the database "FmTFDb" (Bonthala et al., 2014). The availability of this data is expected to greatly accelerate functional genomics in all small millet species.

Lastly, transgenic protocols have been developed for foxtail millet, with both Agrobacterium (Wang et al., 2011) and callus bombardment methods reported (Kothari et al., 2005; Ceasar and Ignacimuthu, 2009; Plaza-Wüthrich and Tadele, 2012), enabling some potentially useful molecular analyses. In one study, a pollen-specific gene has been altered to impair anther function by a co-suppression mechanism (Qin et al., 2008) which might be adapted for the development of male-sterile plants, valuable in breeding foxtail millet hybrid varieties.

\section{Kodo Millet (Paspalum scrobiculatum)}

Kodo millet was domesticated roughly 3000 years ago in India (Figure 2), the only country today where it is harvested as a grain in significant quantities, mainly on the Deccan plateau (Table 1) (de Wet et al., 1983b). The grain contains a diverse range of highquality protein (Geervani and Eggum, 1989; Kulkarni and Naik, 2000), and has high anti-oxidant activity (anti-cancer) even when compared to other millets (Hegde and Chandra, 2005; Hegde et al., 2005; Chandrasekara and Shahidi, 2011b). Like finger millet, kodo is rich in fiber and hence may be useful for diabetics (Geervani and Eggum, 1989). It is drought tolerant and can be grown in a variety of poor soil types from gravelly to clay (de Wet et al., 1983b; M'Ribu and Hilu, 1996). Most genotypes take 4 months to mature (de Wet et al., 1983b). Like foxtail millet, a weedy counterpart of kodo exists and is problematic throughout old-world farming systems especially in damp areas (de Wet et al., 1983b; Becker and Johnson, 2001). It is believed that kodo was probably first harvested as a weed alongside other cereals like rice, perhaps leading to multiple domestication events of the millet across its current range (de Wet et al., 1983b). This practice continues in parts of Africa where the weed is also sometimes harvested during famine (de Wet et al., 1983b; Neumann et al., 1996; Ogie-Odia et al., 2010). In Africa, kodo is referred to as black rice or bird's grass (M'Ribu and Hilu, 1996). Limited molecular marker analysis has shown that kodo millet genotypes cluster by African vs. Indian origin (M'Ribu and Hilu, 1996).

Kodo millet is divided into three races (regularis, irregularis, and variabilis) based on panicle morphology (de Wet et al., 1983b). In southern India, there are small (karu varagu) and large seeded (peru varagu) varieties recognized, often grown together in the same field (de Wet et al., 1983b). General morphological variability is high, with large variance reported in many phenotypic parameters such as time before flowering, tiller number, and yield (Subramanian et al., 2010; Upadhyaya et al., 2014).

Kodo millet is a crop that might be described as incompletely domesticated, with some authors calling the cereal "pseudocultivated" (de Wet, 1992; Blench, 1997). As such, systematic breeding of kodo millet remains neglected but limited efforts have shown promise. Various metrics of plant productivity including dry fodder yield, plant height, and grain yield have revealed good heritability; improvement of these traits has been observed through breeding, with four highly productive genotypes thus far identified (Upadhyaya et al., 2014). Pathogen resistance has been noted as a good breeding target, in particular resistance to smut (Sorosporium paspali and Ustilago spp.) and rust (Puccinia substriata Ellis and Barth), which are both major hindrances of kodo yield (Upadhyaya et al., 2014). Another potential target for breeding may be resistance to the fungi Aspergillus flavus and Aspergillus tamari which produce cyclopiazonic acid that can cause sleepiness, tremors, and giddiness in those that consume infected grain, known as "kodua poisoning" (Rao and Husain, 1985). Grain lodging can occur before harvest, therefore an earlier maturity time might also be targeted (de Wet et al., 1983b). It is also interesting that some cultivated landraces have maintained the perennial nature of their wild ancestor and continue to initiate culms following the maturity of older shoots (de Wet et al., 1983b). If this regeneration trait can be encouraged through breeding and hybridization, it may reduce fertilization inputs and labor.

Unfortunately, no genetic or molecular maps of the kodo millet genome appear to be available (Dwivedi et al., 2012), likely because of the problem of persistent cross-hybridization with its wild relatives. Molecular markers for kodo millet are few, but have been utilized in characterizing diversity and phylogeny (M'Ribu and Hilu, 1996; Kushwaha et al., 2015). There has been some preliminary work in miRNA target site prediction using ESTs from kodo (Babu et al., 2013). In this study, target genes were found be involved in carbohydrate metabolism, cellular transport, and as structural proteins, but a severe lack of kodo DNA information limited this study; the closely-related rice genomic sequence was used for binding-site prediction. With respect to transgene methodology for kodo, the media conditions for callus regeneration protocols have been investigated; regenerated plantlets were successfully grown to maturity in soil (Ceasar and Ignacimuthu, 2010).

ICRISAT conserves 656 accessions of kodo millet, and a core collection has been established that reflects the phenotypic diversity of the entire collection (Upadhyaya et al., 2014). Some universities also maintain large kodo millet seed banks, a good example being the University of Agricultural Sciences in Bangalore (Ceasar and Ignacimuthu, 2010). As the crop is not significant outside of India, there are few reports of other banks with substantial numbers of accessions (Table 2). However, some organizations do keep collections for the purposes of studying the species as a weed as noted above; the US Department of Agriculture has 336 accessions in their National Plant Germplasm System (GRIN) ${ }^{2}$. While seed of African origin does exist in some of these sources, it is rare. Better coverage and ecological exploration of the African continent would help to reveal and preserve diversity of valuable traits which might otherwise be missed by international scientists.

\section{Proso Millet (Panicum miliaceum)}

Proso millet, also called broomcorn and common millet, was domesticated in Neolithic China as early as 10,000 years ago (Figure 2) (Lu et al., 2009). The sequence diversity within proso

${ }^{2}$ http://www.ars-grin.gov/ 
provides evidence for a single site of domestication in the Chinese Loess Plateau (M'Ribu and Hilu, 1994; Hu et al., 2008, 2009). Proso millet expanded across Eurasia and was introduced to North America in the 1700s where it is now primarily used for animal fodder and birdseed (Bagdi et al., 2011). Proso is the true millet referenced in classical European and Middle Eastern sources, referred to by ancient Romans as "milium" (Smith, 1977). Archeological evidence of proso in Eastern Europe dating to 8000 years ago raises the possibility of a secondary independent domestication event, but additional study is needed to confirm this observation (Hunt et al., 2008, 2011). Proso millet was important in the diets of humans across Eurasia prior to the introduction of wheat, barley and potatoes (Kalinova and Moudry, 2006). Today it is only consumed in significant quantities in India (where it is known as pani varagu in Tamil), Nepal, western Myanmar, Sri Lanka, Pakistan, and South East Asian countries (Nirmalakumari et al., 2008). A weedy variety is widespread, which is likely the result of field escape and not due to the spread of the wild ancestor (McCanny and Cavers, 1988). Recent molecular analysis using chromosomal in situ hybridization has implicated Panicum capillare or a close relative as one of the genetic ancestors of proso (Hunt et al., 2014).

The benefits of consuming proso include its high protein content which ranges from 11.3 to $17 \%$ of grain dry matter (Kalinova and Moudry, 2006). Genotypic diversity in protein content and amino acid profile has been observed (Kalinova and Moudry, 2006). Like other small millets, the applicability of the grain in preventing cancer, heart disease, and managing liver disease and diabetes has been investigated with promising results (Nishizawa and Fudamoto, 1995; Nishizawa et al., 2002; Park et al., 2014; Zhang et al., 2014). There may be additional untapped phytochemical value as indicated by a wide range of genotype-specific grain colors (Zhang et al., 2014).

Proso millet is well-adapted to dry sandy soils, and might be the earliest dryland-farming crop in East Asia (Baltensperger, 2002; Lu et al., 2009). It may have the lowest water requirement of any cereal, able to produce harvestable grain with only 330$350 \mathrm{~mm}$ of annual rainfall (Baltensperger, 2002; Seghatoleslami et al., 2008; Hunt et al., 2011). Proso millet matures quickly within 60-90 days, a feature that contributes to its drought resistance and also makes it a good catch-crop (Baltensperger, 2002; Hunt et al., 2014). Genotype has been shown to affect drought tolerance by influencing harvest-index, yield, and water use efficiency (WUE) (Seghatoleslami et al., 2008). In the latter study, a hybrid genotype outperformed local varieties, validating the potential in breeding highly WUE proso millet. Preliminary work in characterizing proso miRNAs has been accomplished with the goal of understanding mechanisms responsible for the cereal's impressive drought resistance (Wu et al., 2012). Despite its drought tolerance, proso is best adapted to temperate latitudes unlike other small millets. It grows further north than any other millet up to a latitude of $54^{\circ} \mathrm{N}$, and at elevations as high as $3500 \mathrm{~m}$ (Baltensperger, 2002). Substantial salinity tolerance has been reported in proso but with significant varietal diversity, with some especially tolerant varieties reported (Sabir et al., 2011; Liu et al., 2015). A higher sodium concentration in roots compared to shoots has been suggested as a biomarker for future breeding efforts (Sabir et al., 2011; Liu et al., 2015).

Cultivated proso millet is divided into five races (Reddy et al., 2007). Race miliaceum resembles wild proso with large, open inflorescences and sub-erect branches with few subdivisions. Patentissimum is very similar to miliaceum with narrow, diffuse panicle branches. These two races are found across the entire Eurasian range of proso, and are considered primitive. Contractum, compactum, and ovatum have more compact inflorescences which are drooped, cylindrical, and curved, respectively (Reddy et al., 2007). ICRISAT holds 842 accessions from all five races (Table 2) (Reddy et al., 2007). The diversity of this collection has been characterized in terms of flowering time, plant height, panicle exsertion, and inflorescence length (Reddy et al., 2007). Other significant collections of proso are summarized in Table 2. Perhaps the largest collection of proso is held by the N.I. Vavilov All-Russian Scientific Research Institute of Plant Industry in St. Petersburg, with roughly 8778 accessions as of 2012 (Dwivedi et al., 2012). Aside from ICRISAT (Upadhyaya et al., 2014), few proso millet core collections appear to exist for breeding purposes. Preliminary diversity clustering based on agronomic traits was performed on the Chinese collection for the purpose of SSRbased characterization (Hu et al., 2009). Perhaps the Chinese subset of 118 landraces could be repurposed and slightly modified to become a true core collection. Explant regeneration techniques have been published for proso, allowing transgenic work to be explored in the future (Plaza-Wüthrich and Tadele, 2012).

The genetic sequence diversity of proso has been examined to a limited degree. The sequence diversity is moderate to high (Karam et al., 2006; Cho et al., 2010; Hunt et al., 2011), perhaps due to continuing hybridization with wild varieties (Colosi and Schaal, 1997). Molecular markers in proso have often been derived from the available sequence data of related species including switchgrass, rice, wheat, barley and oat (Hu et al., 2009; Rajput et al., 2014). AFLP markers have shown promise in grouping proso based on biotype, but were insufficient in differentiating between wild and cultivated varieties (Karam et al., 2004). To the best of our knowledge, no genetic or molecular maps of the proso millet genome are available (Dwivedi et al., 2012).

Like kodo millet, waxy varieties of proso grain exist and are preferred in some areas of Asia because of their glutinous nature-again to facilitate consumption with chopsticks (Graybosch and Baltensperger, 2009). Clustering by geographical sequence diversity corresponds with this regional preference (Hu et al., 2008). Like other glutinous cereals, waxy types of proso have no detectable amylose in the seed endosperm, due to a mutation in the Waxy gene (Hunt et al., 2010). Molecular markers have been developed to identify these waxy genotypes and breed glutinous varieties that are highly valued by consumers (Araki et al., 2012). Proso has been compared to maize in its ethanol production ability, and fermentation efficiency was found to be the highest in waxy varieties (Rose and Santra, 2013). The authors suggest that encouraging the fermentation of proso millet could help stabilize its price in the USA where it is already grown for birdseed and fodder. Finally, proso millet has been utilized as a model organism for $\mathrm{C} 4$ carbon metabolism, specifically in the study of aspartate aminotransferase and malate translocation 
which both contribute to the higher efficiency of C4 photosynthesis (Taniguchi et al., 1995; Taniguchi and Sugiyama, 1996, 1997; Sentoku et al., 2000).

\section{Barnyard Millet (Echinochloa spp.)}

Although sometimes referred to as a single taxonomic group, barnyard millet is composed of two separate species belonging to the genus Echinochloa. Echinochloa esculenta (syn. Echinochloa utilis, Echinochloa crusgalli) is cultivated in Japan, Korea, and the northeastern part of China while Echinochloa frumentacea (syn. Echinochloa colona) is found in Pakistan, India, Nepal, and central Africa (Table 1) (Yabuno, 1987; Wanous, 1990). Both species have overlapping morphological traits that make differentiation problematic. Visual identification is only possible based on the presence or absence of an awn and subtle differences in spikelet and glume morphology (de Wet et al., 1983c). Consequently, the common names Japanese and Indian barnyard millet have been suggested to simplify research and investigation of their phylogeny (Yabuno, 1987). Despite having such strong phenotypic similarities, cytology and marker work have shown the two millets to be genetically distinct; $F_{1}$ hybrids of the two species are sterile (Yabuno, 1962; Hilu, 1994). Both species are known for their fast maturity, high storability, and the ability to grow on poor soil (Yabuno, 1987). ICRISAT currently holds 743 accessions of these barnyard millets from nine countries, with a core collection of 89 varieties recently established (Upadhyaya et al., 2014). Other significant collections can be found at NIAS and the USDA (Hilu, 1994). Sequence data and genetic map availability for both millets are generally low (Dwivedi et al., 2012). Initial transgenic work has been reported on the Japanese variety, but callus regeneration protocols have been reported for both species (Gupta et al., 2001; Kothari et al., 2005).

In addition to the two cultivated species, research has also been conducted on 20-30 wild Echinochloa barnyard millet relatives, some of which have agriculturally interesting traits including rice-mimicry and perennial growth habit. Hybridization within the genus is rampant, and is thought to have contributed to the evolution and current diversity of barnyard millets (Hilu, 1994; Yamaguchi et al., 2005).

\section{Japanese Barnyard Millet (Echinochloa esculenta)}

Japanese barnyard millet originated in eastern Asia (Figure 2) from its wild counterpart E. crus-galli, "barnyard grass" (Yabuno, 1987; Hilu, 1994). It can be differentiated from the Indian species by its larger, awned spikelets with glumes that appear papery instead of membranous (de Wet et al., 1983c). It is tolerant to cold and was historically grown in areas where the climate or land did not suit rice production, particularly in the north of Japan (Yabuno, 1987). In Japan, folklore states that barnyard millet originated from the dead body of a god. Along with proso millet, it makes up part of the "Gokoku," a general term for five staple grains (Yabuno, 1987). Japanese barnyard millet has been found in the coffins of 800 -year-old mummies from the Iwate prefecture, and documents from the 1700s list different cultivars organized by maturity time (Yabuno, 1987). Its historical importance might be attributed to the relief it provided in times of rice crop failure. However, Japanese barnyard millet production has sharply decreased in the last century due to the introduction of cold-tolerant rice varieties and better irrigation practices (Yabuno, 1987). Nevertheless, today it remains the most common millet consumed in Japan, with reported health benefits common to many of the small millets such as its ability to lower plasma glucose concentration, insulin, adiponectin and tumor necrosis factor- $\alpha$ when fed to diabetic mice (Nishizawa et al., 2009). The protein content of Japanese barnyard millet is twice as high as that of rice (Yabuno, 1987). Across genotypes there is diversity in the levels of proteins and healthy lipids, with one genotype suggested as having particularly beneficial antioxidant activity (Kim et al., 2011).

Unlike other small millets consumed in East Asian countries such as foxtail and proso, barnyard millet has no glutinous variety. However, some landraces have been identified which contain very low levels of amylose due to a deletion in one of three waxy genes. One such landrace, "Noge-Hie," was treated with $\gamma$ radiation resulting in progeny lacking the Waxy $(\mathrm{Wx})$ protein (Hoshino et al., 2010). The trait was stably inherited, and this new glutinous variety ("Chojuromochi" in Japan) might be useful for increasing demand for millet products among Japanese consumers.

The morphological and physiological diversity of Japanese barnyard millet is suggested to be high (Nozawa et al., 2006). Flowering time, inflorescence shape, and spikelet pigmentation, among other features, vary across landraces. The species can be grouped into the races utilis and intermedia (Upadhyaya et al., 2014). Molecular diversity studies for Japanese barnyard millet have begun using the non-coding regions of chloroplast DNA as well as nuclear molecular markers (RAPDs, SSRs) and isozymes, although these studies appear to be limited in their sample number (Hilu, 1994; Nakayama et al., 1999; Yamaguchi et al., 2005; Nozawa et al., 2006). Though DNA sequence information in Japanese barnyard millet is otherwise lacking, studies performed on the closely related barnyard grass (E. crus-galli) have generated important sequence information. For example, extensive transcriptomic profiling and annotation have been performed on herbicide resistant varieties of barnyard grass resulting in 74 ESTs, which might be adapted to the study of the cultivated relative ( $\mathrm{Li}$ et al., 2013; Yang et al., 2013).

\section{Indian Barnyard Millet (E. frumentacea)}

Indian barnyard millet, or sawa, was domesticated in India (Figure 2) across its current range from its wild counterpart E. colona, "jungle rice" (Yabuno, 1987; Hilu, 1994). In India, this millet is either harvested as a weed along with a main crop or is grown in a mixture with finger millet and foxtail millet (Gupta et al., 2009b). It is generally cultivated on hilly slopes in tribal areas where few other agricultural options exist and is indispensible in the northwest Himalayan region (Gupta et al., 2009b). Quick maturity makes the species well-adapted to regions with little rainfall (Channappagoudar et al., 2008). Indian barnyard millet contains antifeedants which are present at concentrations higher than in rice, and it displays resistance to the feeding activity of brown planthopper (Kim et al., 2008). In central Africa it is fermented to make beer or used for food, and has been found in the intestines of pre-dynastic Egyptian mummies (de Wet et al., 
1983c). When fed to diabetic humans, significant reductions of blood glucose levels and LDL cholesterol have been reported (Ugare et al., 2014).

Significant phenotypic variation is observed in Indian barnyard millet. Four morphological races (laxa, robusta, intermedia, and stolonifera) were recognized by de Wet in 1983 based on the lengths of flag leaves, peduncles, inflorescences, racemes, as well as plant height and basal tiller number. Race laxa is endemic to the Sikkim Himalayas and only available in a few collections (de Wet et al., 1983c). More recently, a variety of morphological parameters were examined, and principle component analysis (PCA) indicated three morphotypes corresponding to races robusta, intermedia, and stolonifera; laxa was absent suggesting that efforts must be made to collect more of this race (Gupta et al., 2009 b). The authors saw high variability in grain yield, straw yield, and number of productive tillers. They report that the number of racemes, flag leaf width, and internode length showed high correlation with grain yield and should be considered by breeders when performing selections, and promising donor genotypes of these and other traits have been reported (Channappagoudar et al., 2008; Gupta et al., 2009b). Variation across genotypes in photosynthesis and related traits such as transpiration and stomatal conductance has also been observed (Subrahmanyam and Rathore, 1999). Grain smut (Ustilago panici-frumentacei) is a major hindrance of yield, but progress has been made in advanced breeding lines which display low susceptibility when compared to other accessions in which high variability remains (Gupta et al., 2009a).

An early study (Hilu, 1994) using RAPD markers suggested that the sequence diversity of Indian barnyard millet is significantly higher than the Japanese species, perhaps because of multiple domestication events in different locations across India (Hilu, 1994). Variation of markers was $44 \%$, which is high when considering the inbreeding nature of the crop (Hilu, 1994). However, more comprehensive studies are needed that utilize a greater number of molecular markers and genotypes. Similarly, DNA sequence analyses are lacking in Indian barnyard millet.

\section{Little Millet (Panicum sumatrense)}

Also called sama, little millet is cultivated to a limited extent in India, Sri Lanka, Pakistan, Myanmar, and other South East Asian countries (Table 1) (Hiremath et al., 1990). In India it is important to tribes of the Eastern Ghat mountains and grown in combination with other millets (Hiremath et al., 1990). Little millet is a domesticated form of the weedy species Panicum psilopodium (de Wet et al., 1983a). The chromosomes of hybrids of Panicum sumatrense and $P$. psilopodium pair almost perfectly with only a single quadrivalent, indicating that divergence between the two species may have initially occurred through a single reciprocal translocation (Hiremath et al., 1990). Hybrid plants are fertile and vigorous with non-shattering spikelets, and thus introgression of genes between the two species is common (Hiremath et al., 1990). This hybridization ability combined with its wide range of cultivation across India suggests that little millet was domesticated independently several times, although exact dates remain undetermined (de Wet et al., 1983a). Little millet is comparable to other cereals in terms of fiber, fat, carbohydrates, and protein, and rich in phytochemicals including phenolic acids, flavonoids, tannins, and phytate (Pradeep and Guha, 2011). Like many other small millets, it is drought, pest and salt tolerant (Sivakumar et al., 2006b; Bhaskaran and Panneerselvam, 2013; Ajithkumar and Panneerselvam, 2014). The time to maturity for most cultivars is about 90 days (de Wet et al., 1983a).

Little millet is divided into two races based on panicle morphology, nana and robusta. Race nana matures faster and produces less biomass than robusta (de Wet et al., 1983a). In a tribal area of the Indian Kolli hills, diversity among locally grown landraces of little millet was found to be high for all morphological traits measured both within and between landraces despite a small sampling area (Arunachalam et al., 2005). High diversity, heritability and genetic advancement was observed in terms of yield and productive tillers in a collection of 109 landraces, meaning that the crop might be a good candidate for varietal development (Nirmalakumari et al., 2010). A different collection of 460 accessions of little millet held by ICRISAT displayed genetic variation for most of the traits examined (Upadhyaya et al., 2014). A core collection of 56 genotypes was identified which was representative of the entire seed bank. Increased heritable lodging resistance has been introduced to a population of little millet with $\gamma$-ray mutational breeding (Nirmalakumari et al., 2007).

The molecular biology of little millet has been explored to a limited extent. As part of a study to identify seven millet species based on their chloroplast DNA, the trnS-psbC gene region was characterized and subjected to RFLP analysis (Parani et al., 2001). This study showed that it was possible to distinguish all the millet species when the enzymes HaeIII and MspI were used in combination. To investigate mechanisms behind little millet's high prolamine content, a zein-like storage protein was isolated and sequenced (Sivakumar et al., 2006a). Furthermore, $\alpha$-amylase from little millet has been isolated and characterized in terms of biomass and optimum pH (Usha et al., 2011). To the best of our knowledge, no protocols for callus regeneration or transgenic technology have been published. Little millet is perhaps the least studied of the small millet species and there is much that requires investigation, including the establishment of a genetic map and sequenced genome.

\section{Trends, Gaps and Recommendations on How to Foster Diversity within Orphaned Small Millets for the New Green Revolution}

The World Summit on Food Security has set a target of $70 \%$ more food production by 2050, requiring annual increases of 44 million tons, 38\% above current annual increases (Tester and Langridge, 2010). Climate change will cause additional difficulties as many regions are becoming drier with increasingly severe weather patterns (Dai, 2011), and fossil-fuel based nitrogen use is increasingly restricted by legislation intended to slow climate change (Tester and Langridge, 2010). The small millets have the potential to meet these challenges, given their drought tolerance and ability to grow under low input conditions, along with other health-promoting traits valued by humans. Unfortunately, the small millets suffer from low yields (only 0.8 tons grain per hectare) (Plaza-Wüthrich and Tadele, 2012). For the small millets to succeed, priority traits for breeding will need to include 
improving yield under stress conditions (low input, salt, drought, pests, pathogens). Fortunately, an attractive feature of the small millets is that they continue to be cultivated in remote areas which has preserved their biodiversity, giving breeders potential access to unique genes for crop improvement. Due to limited resources, however, current efforts thus far have concentrated primarily on characterizing and reporting the extensive diversity present in seed banks, with few genetic and genomic tools available to exploit this biodiversity for crop improvement. A further challenge in some species (e.g., foxtail millet) is persistent cross-hybridization with wild relatives. Improved varieties of small millets could play a role in the "New Green Revolution"a term coined to reflect novel strategies which will be required to deal with complex challenges in developing nations including increasing population and ever-diminishing arable land (Den Herder et al., 2010).

\section{Exploiting Diversity within Seed Banks}

Diversity is the basis of crop improvement. As described in this review, the small millets possess considerable morphological and genetic sequence variation that can be used by breeders to generate improved varieties. Seed banks across the globe conserve collections of small millets as shown in Table 2, but a challenge is that less diverse germplasm is available for species that are cultivated in a limited geographic region. For example, little millet, which is mainly grown in the Eastern Ghats of India, is represented by a collection of only 466 accessions (Upadhyaya et al., 2014). By contrast, ICRISAT currently holds 6804 accessions of finger millet, a crop widely grown on 1.8 million ha throughout India with extensive cultivation in Eurasia and Africa $^{3}$. Core collections follow the same patterns, with several reported for finger millet but only one for little millet (Upadhyaya et al., 2014). It is essential that core collections be established for all of the millets, however, especially at larger seed banks, to facilitate efficient trait selection. As modern small millet cultivation for human consumption typically occurs in poor nations (with some exceptions), the seed bank infrastructure and associated reporting in the scientific literature and in online databases is sparse and difficult for breeders from foreign nations to access. Furthermore, trait descriptions for each accession are often not reported. Improved funding, coordination, communication and sharing of genetic resources are needed to overcome these problems.

\section{Harvesting Genes from the Wild}

Though interspecific hybrids between some cultivated and wild millets can be problematic, the wild relatives of the small millets may serve as donors of useful genes for crop improvement (e.g., herbicide resistance). To enable breeding, the hybridization ability of Indian and Japanese barnyard millet (Yabuno, 1962; de Wet et al., 1983c) may thus serve as an advantage. However, full realization of this breeding potential may require embryo rescue techniques to bring weak $\mathrm{F}_{1}$ progeny to adulthood (PlazaWüthrich and Tadele, 2012) and better access by breeding programs to wild germplasm (Hajjar and Hodgkin, 2007). Today, the

${ }^{3}$ http://www.icrisat.org/crop-fingermillet.htm wild germplasm is sometimes studied only from a weed science perspective (Peterson and Nalewaja, 1992; Dilday et al., 2001).

\section{Combining Traditional Knowledge of Diversity with Modern Techniques}

Small millets are often grown in remote regions of the world, and hence significant traditional knowledge of millet diversity persists that can serve as a valuable resource for crop improvement. Isolated farming communities often cultivate dozens of locally known millet landraces that are valued for a wide variety of traits (e.g., short duration to combat delayed rains as the result of climate change). Farmers use a complex system to classify their landraces, and in some instances this classification is considered more informative than scientific phylogeny (Rengalakshmi, 2005). On the opposite end of the technological spectrum, research using simple DNA barcoding in lieu of larger numbers of molecular markers is being attempted to classify the small millets down to the landrace level (Newmaster et al., 2013). A unique opportunity in the small millets is combining traditional knowledge with molecular techniques to characterize diversity for the purposes of crop improvement.

\section{The Need for Complete Linkage Maps, Molecular Markers and Genome Sequences}

As described above, in some species, markers including RFLPs, AFLPs, ESTs, and SSRs have been linked to beneficial traits including stress tolerance (Lata et al., 2011). Other, less conventional selective biomarkers have been suggested including differing ratios of transcription factors under stress (Gupta et al., 2014a). However, several small millets lack molecular and genetic markers (e.g., little millet and kodo millet) and no robust linkage maps appear to exist (Dwivedi et al., 2012). Genome and EST sequencing efforts will assist in the development of molecular markers in these species, along with using reference genomes (e.g., from major cereal relatives) to identify orthologous markers. Currently, only the foxtail millet genome has been sequenced and published (Bennetzen et al., 2012; Zhang et al., 2012).

\section{Advances in Transgene Research and Molecular Mechanisms}

As noted in this review, detailed protocols for callus regeneration and transgene protocols have been published for all small millet species except little millet (Kothari et al., 2005; Ceasar and Ignacimuthu, 2009; Plaza-Wüthrich and Tadele, 2012). Since small millet women farmers toil in the drudgery of removing weeds manually (Rengalakshmi, 2005), an attractive transgene trait may be glyphosate herbicide resistance (RoundupReady).

As the small millets are respected by traditional farmers for their extreme abiotic and biotic stress resistance, an understanding of the molecular mechanisms underlying these traits may lead to agronomic improvement of related major cereals. Unfortunately millet diversity remains largely unexplored at the level of molecular mechanism, with the exception of a limited number of studies noted earlier. One especially attractive target will be to understand the ability of barnyard millet to grow under extremely low nitrogen conditions. 


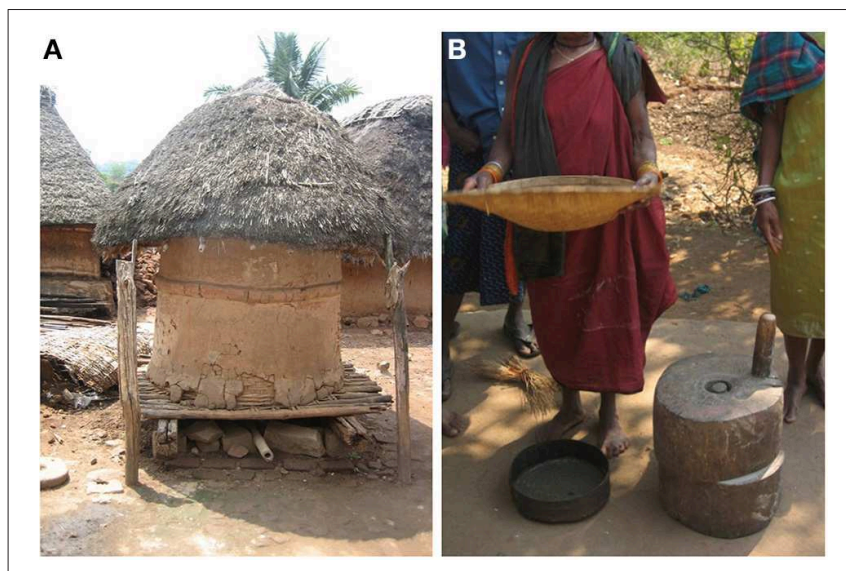

FIGURE 3 | Indigenous technologies and practices of modern small millet farmers. (A) A typical granary in the Eastern Ghats of India used for small millet storage. (B) A woman farmer in Northern India holds a basket used for separating millet grain from chaff. She stands beside a manual millstone used for grinding millet grain into flour. Source: M. Raizada.

\section{Socio-Economic Constraints}

Despite the promise of the small millets, various socio-economic constraints have limited their consumption and hence contributed to a loss of cultivated diversity:

First, a major reason why the small millets are declining in production is that these crops are typically labor-intensive; women are often responsible for manual post-harvest processing, grain threshing and milling (Rengalakshmi, 2005) (Figure 3). To overcome this obstacle, inexpensive machinery is needed.

As noted above, a second challenge to greater adoption of small millets is their comparatively low yield (Plaza-Wüthrich and Tadele, 2012) as a result of the lack of scientific attention. However, the benefits of adding millet to the cropping system may outweigh the drawbacks of low yield (e.g., to combat local protein deficiency or crop failure in stressful environments) (Plaza-Wüthrich and Tadele, 2012). Furthermore, the small millets can be grown in very stressful environments, where major cereals may fail.

Third, family-farm-level diversity is heavily affected by community access to seed which may be limited by current rural seed systems (Nagarajan et al., 2007). However, the presence of local seed markets has been found to increase millet diversity indicating that such markets may serve as good points of introduction for improved varieties.

Finally, agricultural policies in different nations have negatively impacted the cultivation and research of small millets. Production in many areas is becoming displaced by mainstream cereals: in Kenya, the focus has been placed on the cultivation of maize instead of finger millet (Dida et al., 2008), while in Northern Japan, cold-tolerant rice has almost completely replaced barnyard millet (Yabuno, 1987). Reduced cultivation of these millets in financially-rich countries like Japan is problematic, because it may decrease global research funding for these crops. However, recent reports revealing medicinal and nutritional benefits of these species (absence of gluten, cancer inhibition, control of blood-glucose and cholesterol) might catalyze consumer interest and hence funding in the developed world (Hegde et al., 2005; Nishizawa et al., 2009; Kim et al., 2011; Zhang et al., 2014). Nevertheless, landraces from these areas should be preserved in seed banks to ensure their conservation.

Given these socio-economic constraints, millets must not be blindly advocated in the developing world in biodiversity strategies. Prior to their introduction, multi-disciplinary surveys must be undertaken with local farmers concerning their nutrition, seed availability, economy, climate, and other crops in the cropping system.

\section{Conclusions}

Modern agriculture is characterized by dominance of a few crop species with a trend toward genetic homogenization as a result of the global exchange of alleles via breeding. In contrast, traditional farmer landraces of the small millets continue to be cultivated under relative genetic isolation, and hence provide living examples of genetic and phenotypic biodiversity in contemporary agriculture. The small millets are valued by traditional farmers for their nutritional content and health promoting properties, ability to grow under low input conditions and tolerance to extreme environmental stress, especially drought. In a world facing limiting natural resources and climate change, these crops thus hold tremendous potential as valuable instruments in the toolkit of the New Green Revolution. It is hoped that germplasm resources combined with modern genomic tools can help to accelerate exploitation of this biodiversity.

\section{Author Contributions}

Both TG and MR conceived of the manuscript. TG wrote the manuscript and MR edited the manuscript. Both authors read and approved the final manuscript.

\section{Acknowledgments}

We thank Dr. Malinda Thilakarathna (University of Guelph, Raizada Lab) for providing photos of millet cropping systems, and Dr. Kirit Patel (Canadian Mennonite University) for inspiring this review. TG received partial scholarship support from the Queen Elizabeth II Graduate Scholarship in Science and Technology and additional support from a grant to MR from the International Development Research Centre (IDRC) and the Canadian Department of Foreign Affairs, Trade and Development (DFATD) as part of the CIFSRF program. 


\section{References}

Abrahamson, S., Bender, M. A., Conger, A. D., and Wolff, S. (1973). Uniformity of radiation-induced mutation rates among different species. Nature 245, 460-462. doi: 10.1038/245460a0

Aduguna, A. (2007). The role of introduced sorghum and millets in Ethiopian agriculture. SAT J. 3, 1-4.

Ajithkumar, I. P., and Panneerselvam, R. (2014). ROS scavenging system, osmotic maintenance, pigment and growth status of Panicum sumatrense roth. Under drought stress. Cell Biochem. Biophys. 68, 587-595. doi: 10.1007/s12013-0139746-x

Anjaneyulu, E., Reddy, P. S., Sunita, M. S., Kishor, P. B., and Meriga, B. (2014). Salt tolerance and activity of antioxidative enzymes of transgenic finger millet overexpressing a vacuolar H+-pyrophosphatase gene (SbVPPase) from Sorghum bicolor. J. Plant Physiol. 171, 789-798. doi: 10.1016/j.jplph.2014.02.001

Araki, M., Numaoka, A., Kawase, M., and Fukunaga, K. (2012). Origin of waxy common millet, Panicum miliaceum L. in Japan. Genet. Res. Crop Evol. 59, 1303-1308. doi: 10.1007/s10722-011-9755-9

Arunachalam, V., Rengalakshmi, R., and Raj, M. S. K. (2005). Ecological stability of genetic diversity among landraces of little millet (Panicum sumatrense) in south India. Genet. Res. Crop Evol. 52, 15-19. doi: 10.1007/s10722-005-6693-4

Babu, B. K., Agrawal, P. K., Pandey, D., Jaiswal, J. P., and Kumar, A. (2014a). Association mapping of agro-morphological characters among the global collection of finger millet genotypes using genomic SSR markers. Mol. Biol. Rep. 41, 5287-5297. doi: 10.1007/s11033-014-3400-6

Babu, B. K., Agrawal, P. K., Pandey, D., and Kumar, A. (2014b). Comparative genomics and association mapping approaches for opaque 2 modifier genes in finger millet accessions using genic, genomic and candidate gene-based simple sequence repeat markers. Mol. Breed. 34, 1261-1279. doi: 10.1007/s11032-0140115-2

Babu, B. K., Dinesh, P., Agrawal, P. K., Sood, S., Chandrashekara, C., Bhatt, J. C., et al. (2014c). Comparative genomics and association mapping approaches for blast resistant genes in finger millet using SSRs. PLoS ONE 9:e99182. doi: 10.1371/journal.pone.0099182

Babu, B. K., Pandey, D., Agrawal, P. K., Sood, S., and Kumar, A. (2014d). Insilico mining, type and frequency analysis of genic microsatellites of finger millet (Eleusine coracana (L.) Gaertn.): a comparative genomic analysis of NBSLRR regions of finger millet with rice. Mol. Biol. Rep. 41, 3081-3090. doi: 10.1007/s11033-014-3168-8

Babu, R. N., Jyothi, M. N., Sharadamma, N., Sahu, S., Rai, D. V., and Devaraj, V. R. (2013). Computational identification of conserved micro RNAs from kodo millet (Paspalum scrobiculatum). Afr. Crop Sci. J. 21, 75-83.

Bagdi, A., Balázs, G., Schmidt, J., Szatmári, M., Schoenlechner, R., Berghofer, E., et al. (2011). Protein characterization and nutrient composition of Hungarian proso millet varieties and the effect of decortication. Acta Aliment. 40, 128-141. doi: 10.1556/AAlim.40.2011.1.15

Bai, H., Cao, Y., Quan, J., Dong, L., Li, Z., Zhu, Y., et al. (2013). Identifying the genome-wide sequence variations and developing new molecular markers for genetics research by re-sequencing a landrace cultivar of foxtail millet. PLoS ONE 8:e73514. doi: 10.1371/journal.pone.0073514

Baltensperger, D. D. (1996). "Foxtail and proso millet," in Trends in New Crops and New Uses, eds J. Janick and A. Whipkey (Alexandria: ASHS Press), 182-190.

Baltensperger, D. D. (2002). "Progress with proso, pearl and other millets," in Trends in New Crops and New Uses, eds J. Janick and A. Whipkey (Alexandria: ASHS Press), 100-103.

Becker, M., and Johnson, D. E. (2001). Cropping intensity effects on upland rice yield and sustainability in West Africa. Nutr. Cycl. Agroecosyst. 59, 107-117. doi: 10.1023/A:1017551529813

Benin, S., Smale, M., Pender, J., Gebrernedhin, B., and Ehui, S. (2004). The economic determinants of cereal crop diversity on farms in the Ethiopian highlands. Agric. Econ. 31, 197-208. doi: 10.1111/j.1574-0862.2004.tb00257.x

Bennetzen, J. L., Schmutz, J., Wang, H., Percifield, R., Hawkins, J., Pontaroli, A. C., et al. (2012). Reference genome sequence of the model plant Setaria. Nat. Biotechnol. 30, 555-561. doi: 10.1038/nbt.2196

Bhaskaran, J., and Panneerselvam, R. (2013). Accelerated reactive oxygen scavenging system and membrane integrity of two Panicum species varying in salt tolerance. Cell Biochem. Biophys. 67, 885-892. doi: 10.1007/s12013-0139576-x
Bhatt, D., Negi, M., Sharma, P., Saxena, S. C., Dobriyal, A. K., and Arora, S. (2011). Responses to drought induced oxidative stress in five finger millet varieties differing in their geographical distribution. Physiol. Mol. Biol. Plants 17, 347-353. doi: 10.1007/s12298-011-0084-4

Bisht, M. S., and Mukai, Y. (2001). Genomic in situ hybridization identifies genome donor of finger millet (Eleusine coracana). Theor. Appl. Genet. 102, 825-832. doi: $10.1007 / \mathrm{s} 001220000497$

Blench, R. (1997). Neglected species, livelihoods and biodiversity in difficult areas: how should the public sector respond? Nat. Resour. Perspect. 23, 1-10.

Bonthala, V. S., Muthamilarasan, M., Roy, R., and Prasad, M. (2014). FmTFDb: a foxtail millet transcription factors database for expediting functional genomics in millets. Mol. Biol. Rep. 41, 6343-6348. doi: 10.1007/s11033-0143574-y

Borlaug, N. E. (2000). Ending world hunger. The promise of biotechnology and the threat of antiscience zealotry. Plant Physiol. 124, 487-490. doi: 10.1104/pp.124.2.487

Brown, A. H. D. (1989). Core collections: a practical approach to genetic resources management. Genome 31, 818-824. doi: 10.1139/g89-144

Burton, G. W. (1940). A cytological study of some species in the genus Paspalum. J. Agric. Res. 60, 193-198.

Cakmak, I. (2008). Enrichment of cereal grains with zinc: Agronomic or genetic biofortification? Plant Soil 302, 1-17. doi: 10.1007/s11104-007-9466-3

Ceasar, S. A., and Ignacimuthu, S. (2009). Genetic engineering of millets: current status and future prospects. Biotechnol. Lett. 31, 779-788. doi: 10.1007/s10529009-9933-4

Ceasar, S. A., and Ignacimuthu, S. (2010). Effects of cytokinins, carbohydrates and amino acids on induction and maturation of somatic embryos in kodo millet (Paspalum scorbiculatum Linn.). Plant Cell Tissue Organ Cult. 102, 153-162. doi: 10.1007/s11240-010-9716-6

Ceasar, S. A., and Ignacimuthu, S. (2011). Agrobacterium-mediated transformation of finger millet (Eleusine coracana (L.) Gaertn.) using shoot apex explants. Plant Cell Rep. 30, 1759-1770. doi: 10.1007/s00299-011-1084-0

Chandrasekara, A., and Shahidi, F. (2011a). Antiproliferative potential and DNA scission inhibitory activity of phenolics from whole millet grains. J. Funct. Foods 3, 159-170. doi: 10.1016/j.jff.2011.03.008

Chandrasekara, A., and Shahidi, F. (2011b). Determination of antioxidant activity in free and hydrolyzed fractions of millet grains and characterization of their phenolic profiles by HPLC-DAD-ESI-MS. J. Funct. Foods 3, 144-158. doi: 10.1016/j.jff.2011.03.007

Channappagoudar, B. B., Hiremath, S. M., Biradar, N. R., Koti, R. V., and Bharamagoudar, T. D. (2008). Influence of morpho-physiological and biochemical traits on the productivity of barnyard millet. Karnataka J. Agric. Sci. 20, $477-480$.

Cho, Y.-I., Chung, J.-W., Lee, G.-A., Ma, K.-H., Dixit, A., Gwag, J.-G., et al. (2010). Development and characterization of twenty-five new polymorphic microsatellite markers in proso millet (Panicum miliaceum L.). Genes Genomics 32, 267-273. doi: 10.1007/s13258-010-0007-8

Colosi, J. C., and Schaal, B. A. (1997). Wild proso millet (Panicum miliaceum) is genetically variable and distinct from crop varieties of proso millet. Weed Sci. 45, 509-518.

D’Ennequin, M. L. T., Panaud, O., Brown, S., Siljak-Yakovlev, S., and Sarr, A. (1998). First evaluation of nuclear DNA content in Setaria genus by flow cytometry. J. Hered. 86, 556-559.

Dai, A. (2011). Drought under global warming: a review. Wiley Interdiscip. Rev. Clim. Chang. 2, 45-65. doi: 10.1002/wcc.81

Darmency, H., and Pernes, J. (1985). Use of wild Setaria viridis (L.) Beauv. to improve triazine resistance in cultivated S. italica (L.) by hybridization. Weed Res. 25, 175-179. doi: 10.1111/j.1365-3180.1985.tb00633.x

Darmency, H., and Pernes, J. (1989). Agronomic performance of a triazine resistant foxtail millet (Setaria italica (L.) Beauv.). Weed Res. 29, 147-150. doi: 10.1111/j.1365-3180.1989.tb00853.x

De Datta, S. K., Tauro, A. C., and Balaoing, S. N. (1968). Effect of plant type and nitrogen level on the growth characteristics and grain yield of Indica rice in the tropics. Agron. J. 60, 663-647. doi: 10.2134/agronj1968.00021962006000060017x

Den Herder, G., Van Isterdael, G., Beeckman, T., and De Smet, I. (2010). The roots of a new green revolution. Trends Plant Sci. 15, 600-607. doi: $10.1016 /$ j.tplants.2010.08.009 
Devi, P. B., Vijayabharathi, R., Sathyabama, S., Malleshi, N. G., and Priyadarisini, V. B. (2014). Health benefits of finger millet (Eleusine coracana L.) polyphenols and dietary fiber: a review. J. Food Sci. Technol. 51, 1021-1040. doi: 10.1007/s13197-011-0584-9

de Wet, J. M. J. (1992). “The three phases of cereal domestication,” in Grass Evolution and Domestication, ed G. P. Chapman (Cambridge: Cambridge University Press), 176-191.

de Wet, J. M. J., Prasada Rao, K. E., and Brink, D. E. (1983a). Systematics and domestication of Panicum sumatrense (Graminae). J. d'agriculture Tradit. Bot. appliquée 30, 159-168.

de Wet, J. M. J., Rao, K. E. P., Mengesha, M. H., and Brink, D. E. (1983b). Diversity in kodo millet, Paspalum scrobiculatum. Econ. Bot. 37, 159-163. doi: 10.1007/BF02858779

de Wet, J. M. J., Rao, K. E. P., Mengesha, M. H., and Brink, D. E. (1983c). Domestication of sawa millet. Econ. Bot. 37, 283-291. doi: 10.1007/BF02858883

Dida, M. M., and Devos, K. M. (2006). "Finger millet," in Cereals and Millets, ed C. Kole (New York, NY: Springer), 333-343.

Dida, M. M., Srinivasachary, Ramakrishnan, S., Bennetzen, J. L., Gale, M. D., and Devos, K. M. (2007). The genetic map of finger millet, Eleusine coracana. Theor. Appl. Genet. 114, 321-332. doi: 10.1007/s00122-006-0435-7

Dida, M. M., Wanyera, N., Harrison Dunn, M. L., Bennetzen, J. L., and Devos, K. M. (2008). Population structure and diversity in finger millet (Eleusine coracana) germplasm. Trop. Plant Biol. 1, 131-141. doi: 10.1007/s12042-008-9012-3

Dilday, R. H., Mattice, J. D., Moldenhauer, K. A., and Yan, W. (2001). Allelopathic potential in rice germplasm against ducksalad, redstem and barnyard grass. J. Crop Prot. 4, 287-301. doi: 10.1300/J144v04n02_11

Diwan, N., McIntosh, M. S., and Bauchan, G. R. (1995). Methods of developing a core collection of annual Medicago species. Theor. Appl. Genet. 90, 755-761. doi: $10.1007 / \mathrm{BF} 00222008$

Doust, A. N., Kellogg, E. A., Devos, K. M., and Bennetzen, J. L. (2009). Foxtail millet: a sequence-driven grass model system. Plant Physiol. 149, 137-141. doi: $10.1104 / \mathrm{pp} .108 .129627$

Dwivedi, S., Upadhyaya, H., Senthilvel, S., Hash, C., Fukunaga, K., Diao, X., et al. (2012). "Millets: genetic and genomic resources," in Plant Breeding Reviews, ed J. Janick (Hoboken, NJ: John Wiley and Sons, Inc.), 247-374.

Ejeta, G. (2010). African green revolution needn't be a mirage. Science 327, 831-832. doi: 10.1126/science. 1187152

Evenson, R. E., and Gollin, D. (2003). Assessing the impact of the green revolution, 1960 to 2000 . Science 300, 758-762. doi: 10.1126 /science. 1078710

Geervani, P., and Eggum, B. O. (1989). Nutrient composition and protein quality of minor millets. Plant Foods Hum. Nutr. 39, 201-208. doi: 10.1007/BF01091900

Graybosch, R. A., and Baltensperger, D. D. (2009). Evaluation of the waxy endosperm trait in proso millet (Panicum miliaceum). Plant Breed. 128, 70-73. doi: 10.1111/j.1439-0523.2008.01511.x

Gull, A., Jan, R., Nayik, G. A., Prasad, K., and Kumar, P. (2014). Significance of finger millet in nutrition, health and value added products: a review. J. Environ. Sci. Comput. Sci. Eng. Technol. 3, 1601-1608.

Gupta, A., Joshi, D., Mahajan, V., and Gupta, H. S. (2009a). Screening barnyard millet germplasm against grain smut (Ustilago panici-frumentacei Brefeld). Plant Genet. Resour. 8, 52-54. doi: 10.1017/S1479262109990141

Gupta, A., Mahajan, V., Kumar, M., and Gupta, H. S. (2009b). Biodiversity in the barnyard millet (Echinochloa frumentacea Link, Poaceae) germplasm in India. Genet. Resour. Crop Evol. 56, 883-889. doi: 10.1007/s10722-009-9462-y

Gupta, P., Raghuvanshi, S., and Tyagi, A. K. (2001). Assessment of the efficiency of various gene promoters via biolistics in leaf and regenerating seed callus of millets, Eleusine coracana and Echinochloa crusgalli. Plant Biotechnol. 18, 275-282. doi: 10.5511/plantbiotechnology.18.275

Gupta, S., Gupta, S. M., Gupta, A. K., Gaur, V. S., and Kumar, A. (2014a). Fluctuation of Dof1/Dof2 expression ratio under the influence of varying nitrogen and light conditions: involvement in differential regulation of nitrogen metabolism in two genotypes of finger millet (Eleusine coracana L.). Gene 546, 327-335. doi: 10.1016/j.gene.2014.05.057

Gupta, S., Kumari, K., Muthamilarasan, M., Parida, S. K., and Prasad, M. (2014b). Population structure and association mapping of yield contributing agronomic traits in foxtail millet. Plant Cell Rep. 33, 881-893. doi: 10.1007/s00299-0141564-0

Gupta, S., Kumari, K., Sahu, P. P., Vidapu, S., and Prasad, M. (2012). Sequencebased novel genomic microsatellite markers for robust genotyping purposes in foxtail millet [Setaria italica (L.) P. Beauv]. Plant Cell Rep. 31, 323-337. doi: $10.1007 / \mathrm{s} 00299-011-1168-\mathrm{x}$

Hajjar, R., and Hodgkin, T. (2007). The use of wild relatives in crop improvement: a survey of developments over the last 20 years. Euphytica 156, 1-13. doi: $10.1007 /$ s10681-007-9363-0

Heap, I. M. (1997). The occurrence of herbicide-resistant weeds worldwide. Pestic. Sci. 51, 235-243.

Hegde, B. R., and Gowda, L. (1986). Cropping systems and production technology for small millets in India. Proc. First Int. Small MilletsWorkshop 209-236.

Hegde, P. S., and Chandra, T. S. (2005). ESR spectroscopic study reveals higher free radical quenching potential in kodo millet (Paspalum scrobiculatum) compared to other millets. Food Chem. 92, 177-182. doi: 10.1016/j.foodchem.2004. 08.002

Hegde, P. S., Rajasekaran, N. S., and Chandra, T. S. (2005). Effects of the antioxidant properties of millet species on oxidative stress and glycemic status in alloxan-induced rats. Nutr. Res. 25, 1109-1120. doi: 10.1016/j.nutres.2005.09.020

Hema, R., Vemanna, R. S., Sreeramulu, S., Reddy, C. P., Senthil-Kumar, M. and Udayakumar, M. (2014). Stable expression of $m t l D$ gene imparts multiple stress tolerance in finger millet. PLoS ONE 9:e99110. doi: 10.1371/journal.pone.0099110

Hilu, K. W. (1994). Evidence from RAPD markers in the evolution of Echinochloa millets (Poaceae). Plant Syst. Evol. 189, 247-257. doi: 10.1007/BF00939730

Hirano, R., Naito, K., Fukunaga, K., Watanabe, K. N., Ohsawa, R., and Kawase, M. (2011). Genetic structure of landraces in foxtail millet (Setaria italica (L.) P. Beauv.) revealed with transposon display and interpretation to crop evolution of foxtail millet. Genome 54, 498-506. doi: 10.1139/g11-015

Hiremath, S. C., Patil, G. N. V., and Salimath, S. S. (1990). Genome homology and origin of Panicum sumatrense (Gramineae). Cytologia (Tokyo). 55, 315-319. doi: $10.1508 /$ cytologia.55.315

Hoshino, T., Nakamura, T., Seimiya, Y., Kamada, T., Ishikawa, G., Ogasawara, A., et al. (2010). Production of a fully waxy line and analysis of waxy genes in the allohexaploid crop, Japanese barnyard millet. Plant Breed. 129, 349-355. doi: 10.1111/j.1439-0523.2009.01668.x

$\mathrm{Hu}$, J., Zhu, J., and Xu, H. M. (2000). Methods of constructing core collections by stepwise clustering with three sampling strategies based on the genotypic values of crops. Theor. Appl. Genet. 101, 264-268. doi: 10.1007/s0012200 51478

Hu, X., Wang, J., Lu, P., and Zhang, H. (2009). Assessment of genetic diversity in broomcorn millet (Panicum miliaceum L.) using SSR markers. J. Genet. Genomics 36, 491-500. doi: 10.1016/S1673-8527(08) 60139-3

Hu, Y. G., Zhu, J., Liu, F., Zhang, Z., Chai, Y., and Weining, S. (2008). Genetic diversity among Chinese landraces and cultivars of broomcorn millet (Panicum miliaceum) revealed by the polymerase chain reaction. Ann. Appl. Biol. 153, 357-364. doi: 10.1111/j.1744-7348.2008.00263.x

Hunt, H. V., Badakshi, F., Romanova, O., Howe, C. J., Jones, M. K., and HeslopHarrison, J. S. P. (2014). Reticulate evolution in Panicum (Poaceae): the origin of tetraploid broomcorn millet, P. miliaceum. J. Exp. Bot. 65, 3165-3175. doi: $10.1093 / \mathrm{jxb} / \mathrm{eru} 161$

Hunt, H. V., Campana, M. G., Lawes, M. C., Park, Y.-J., Bower, M. A., Howe, C., et al. (2011). Genetic diversity and phylogeography of broomcorn millet (Panicum miliaceum L.) across Eurasia. Mol. Ecol. 20, 4756-4771. doi: 10.1111/j.1365-294X.2011.05318.x

Hunt, H. V., Denyer, K., Packman, L. C., Jones, M. K., and Howe, C. J. (2010). Molecular basis of the waxy endosperm starch phenotype in broomcorn millet (Panicum miliaceum L.). Mol. Biol. Evol. 27, 1478-1494. doi: 10.1093/molbev/msq040

Hunt, H. V., Vander Linden, M., Liu, X., Motuzaite-Matuzeviciute, G., Colledge, S., and Jones, M. K. (2008). Millets across Eurasia: chronology and context of early records of the genera Panicum and Setaria from archaeological sites in the Old World. Veg. Hist. Archaeobot. 17, S5-S18. doi: 10.1007/s00334-0080187-1

Jagga-Chugh, S., Kachhwaha, S., Sharma, M., Kothari-Chajer, A., and Kothari, S. L. (2012). Optimization of factors influencing microprojectile bombardmentmediated genetic transformation of seed-derived callus and regeneration of transgenic plants in Eleusine coracana (L.) Gaertn. Plant Cell Tissue Organ Cult. 109, 401-410. doi: 10.1007/s11240-011-0104-7 
Jarret, R. L., Ozias-Akins, P., Phatak, S., Nadimpalli, R., Duncan, R., and Hiliard, S. (1995). DNA contents in Paspalum spp. determined by flow cytometry. Genet. Resour. Crop Evol. 42, 237-242. doi: 10.1007/BF02431258

Jayaraman, A., Puranik, S., Rai, N. K., Vidapu, S., Sahu, P. P., Lata, C., et al. (2008). cDNA-AFLP analysis reveals differential gene expression in response to salt stress in foxtail millet (Setaria italica L.). Mol. Biotechnol. 40, 241-251. doi: 10.1007/s12033-008-9081-4

Jia, G., Huang, X., Zhi, H., Zhao, Y., Zhao, Q., Li, W., et al. (2013). A haplotype map of genomic variations and genome-wide association studies of agronomic traits in foxtail millet (Setaria italica). Nat. Genet. 45, 957-961. doi: 10.1038/ng.2673

Jia, X., Zhang, Z., Liu, Y., Zhang, C., Shi, Y., Song, Y., et al. (2009). Development and genetic mapping of SSR markers in foxtail millet [Setaria italica (L.) P. Beauv.]. Theor. Appl. Genet. 118, 821-829. doi: 10.1007/s00122-008-0942-9

Jusuf, M., and Pernes, J. (1985). Genetic variability of foxtail millet (Setaria italica P. Beauv.): electrophoretic study of five isoenzyme systems. Theor. Appl. Genet. 71, 385-391. doi: 10.1007/BF00251177

Kalinova, J., and Moudry, J. (2006). Content and quality of protein in proso millet (Panicum miliaceum L.) varieties. Plant Foods Hum. Nutr. 61, 45-49. doi: 10.1007/s11130-006-0013-9

Karam, D., Westra, P., Niessen, S. J., Ward, S. M., and Figueiredo, J. E. F. (2006). Assessment of silver-stained AFLP markers for studying DNA polymorphism in proso millet (Panicum miliaceum L.). Rev. Bras. Bot. 26, 609-615. doi: 10.1590/S0100-84042006000400011

Karam, D., Westra, P., Nissen, S. J., Ward, S. M., and Figueiredo, J. E. F. (2004). Genetic diversity among proso millet (Panicum miliaceum) biotypes assessed by AFLP technique. Planta Daninha 22, 167-174. doi: 10.1590/S010083582004000200001

Kawase, M., Fukunaga, K., and Kato, K. (2005). Diverse origins of waxy foxtail millet crops in East and Southeast Asia mediated by multiple transposable element insertions. Mol. Genet. Genomics 274, 131-140. doi: 10.1007/s00438-0050013-8

Kim, C.-S., Alamgir, K. M., Matsumoto, S., Tebayashi, S., and Koh, H.-S. (2008). Antifeedants of Indian barnyard millet, Echinochloa frumentacea Link, against brown planthopper, Nilaparvata lugens (Stal). Z. Naturforsch. 63, 755-760.

Kim, J. Y., Jang, K. C., Park, B.-R., Han, S.-I., Choi, K.-J., Kim, S.-Y., et al. (2011). Physicochemical and antioxidative properties of selected barnyard millet (Echinochloa utilis) species in Korea. Food Sci. Biotechnol. 20, 461-469. doi: 10.1007/s10068-011-0064-z

Kothari, S. L., Kumar, S., Vishnoi, R. K., Kothari, A., and Watanabe, K. N. (2005). Applications of biotechnology for improvement of millet crops: review of progress and future prospects. Plant Biotechnol. 22, 81-88. doi: 10.5511/plantbiotechnology.22.81

Kubešová, M., Moravcova, L., Suda, J., Jarošík, V., and Pyšek, P. (2010). Naturalized plants have smaller genomes than their non-invading relatives: a flow cytometric analysis of the Czech alien flora. Preslia 82, 81-96.

Kulkarni, L. R., and Naik, R. K. (2000). Nutitive value, protein quality and organoleptic quality of kodo millet (Paspalum scrobiculatum). Karnataka J. Agric. Sci. 13, 125-129.

Kumar, A., Gaur, V. S., Goel, A., and Gupta, A. K. (2014a). De novo assembaly and characterization of developing spikes transcriptome of finger millet (Eleusine coracana): a minor crop having nutraceutical properties. Plant Mol. Biol. Rep. doi: 10.1007/s11105-014-0802-5

Kumar, A., Kanwal, P., Gupta, A. K., Singh, B. R., and Gaur, V. S. (2014b). A fulllength Dof1 transcription factor of finger millet and its response to a circadian cycle. Plant Mol. Biol. Rep. 32, 419-427. doi: 10.1007/s11105-013-0653-5

Kumar, A., Mirza, N., Charan, T., Sharma, N., and Gaur, V. S. (2014c). Isolation, characterization and immunolocalization of a seed dominant CaM from finger millet (Eleusine coracana L. Gartn.) for studying its functional role in differential accumulation of calcium in developing grains. Appl. Biochem. Biotechnol. 172, 2955-2973. doi: 10.1007/s12010-013-0714-0

Kushwaha, H., Jillo, K. W., Singh, V. K., Kumar, A., and Yadav, D. (2015). Assessment of genetic diversity among cereals and millets based on PCR amplification using Dof (DNA binding with One Finger) transcription factor gene-specific primers. Plant Syst. Evol. 301, 833-840. doi: 10.1007/s00606-014-1095-8

Lata, C., Bhutty, S., Bahadur, R. P., Majee, M., and Prasad, M. (2011). Association of an SNP in a novel DREB2-like gene SiDREB2 with stress tolerance in foxtail millet [Setaria italica (L.)]. J. Exp. Bot. 62, 3387-3401. doi: 10.1093/jxb/ err016
Lata, C., and Prasad, M. (2013). Validation of an allele-specific marker associated with dehydration stress tolerance in a core set of foxtail millet accessions. Plant Breed. 132, 496-499. doi: 10.1111/j.1439-0523.2012.01983.x

Latha, A. M., Rao, K. V., and Reddy, V. D. (2005). Production of transgenic plants resistant to leaf blast disease in finger millet (Eleusine coracana (L.) Gaertn.). Plant Sci. 169, 657-667. doi: 10.1016/j.plantsci.2005.05.009

Li, C. H., Pao, W. K., and Li, H. W. (1942). Interspecific crosses in Setaria. J. Hered. 33, 351-355.

Li, G., Wu, S., Cai, L., Wang, Q., Zhao, X., and Wu, C. (2013). Identification and mRNA expression profile of glutamate receptor-like gene in quincloracresistant and susceptible Echinochloa crus-galli. Gene 531, 489-495. doi: 10.1016/j.gene.2013.09.013

Li, Y., Wang, J., Cao, Y., Gao, W., Fang, J., and Lou, X. (1998). The use of genetic resources in crop improvement: lessons from China. Genet. Resour. Crop Evol. 45, 181-186. doi: 10.1023/A:1008691532378

Li, Y., and Wu, S. (1996). Traditional maintenance and multiplication of foxtail millet (Setaria italica (L.) P. Beauv.) landraces in China. Euphytica 87, 33-38. doi: 10.1007/BF00022961

Liu, M., Qiao, Z., Zhang, S., Wang, Y., and Lu, P. (2015). Response of broomcorn millet (Panicum miliaceum L.) genotypes from semi arid regions of China to salt stress. Crop J. 3, 57-66. doi: 10.1016/j.cj.2014.08.006

Liu, Q., Jiang, B., Wen, J., and Peterson, P. M. (2014). Low-copy nuclear gene and McGISH resolves polyploid history of Eleusine coracana and morphological character evolution in Eleusine. Turk. J. Bot. 38, 1-12. doi: 10.3906/bot-1305-12

Lu, H., Zhang, J., Liu, K., Wu, N., Li, Y., Zhou, K., et al. (2009). Earliest domestication of common millet (Panicum miliaceum) in East Asia extended to 10,000 years ago. PNAS 106, 7367-7372. doi: 10.1073/pnas.0900158106

M’Ribu, H. K., and Hilu, K. W. (1994). Detection of interspecific and intraspecific variation in Panicum millets through random amplified polymorphic DNA. Theor. Appl. Genet. 88, 412-416.

M'Ribu, H. K., and Hilu, K. W. (1996). Application of random amplified polymorphic DNA to study genetic diversity in Paspalum scrobiculatum L. (Kodo millet, Poaceae). Genet. Resour. Crop Evol. 43, 203-210.

Marles, M. A. S., Devine, M. D., and Hall, J. C. (1993). Herbicide resistance in Setaria viridis conferred by a less sensitive form of acetyl coenzyme a carboxylase. Pesiticide Biochem. Physiol. 46, 7-14. doi: 10.1006/pest.1993.1031

McCanny, S. J., and Cavers, P. B. (1988). Spread of proso millet (Panicum miliaceum L.) in Ontario, Canada. II. Dispersal by combines. Weed Res. 28, 67-72. doi: 10.1111/j.1365-3180.1988.tb00788.x

Morrison, I. N., Todd, B. G., and Nawolsky, K. M. (1989). Confirmation of trifluralin-resistant green foxtail (Setaria viridis) in Manitoba. Weed Technol. 3, 544-551.

Muthamilarasan, M., Venkata Suresh, B., Pandey, G., Kumari, K., Parida, S. K., and Prasad, M. (2014). Development of 5123 intron-length polymorphic markers for large-scale genotyping applications in foxtail millet. DNA Res. 21, 41-52. doi: 10.1093/dnares/dst039

Muza, F. R., Lee, D. J., Andrews, D. J., and Gupta, S. C. (1995). Mitochondrial DNA variation in finger millet (Eleusine coracana L. Gaertn). Euphytica 81, 199-205. doi: 10.1007/BF00025434

Mysore, K. S., and Baird, V. (1997). Nuclear DNA content in species of Eleusine (Gramineae): a critical re-evaluation using laser flow cytometry. Plant Syst. Evol. 207, 1-11. doi: 10.1007/BF00985206

Nagarajan, L., Smale, M., and Glewwe, P. (2007). Determinants of millet diversity at the household-farm and village-community levels in the drylands of India: the role of local seed systems. Agric. Econ. 36, 157-167. doi: 10.1111/j.15740862.2007.00195.x

Nakayama, Y., Umemoto, S., and Yamaguchi, H. (1999). Identification of polyploid groups in the genus Echinochloa by isozyme analysis. J. Weed Sci. Technol. 44, 205-217. doi: 10.3719/weed.44.205

Neumann, K., Ballouche, A., and Klee, M. (1996). The emergence of plant food production in the West African Sahel: new evidence from northeast Nigeria and northern Burkina Faso. Asp. Afr. Archaeol. 441-448.

Newmaster, S. G., Ragupathy, S., Dhivya, S., Jijo, C. J., Sathishkumar, R., and Patel, K. (2013). Genomic valorization of the fine scale classification of small millet landraces in southern India. Genome 56, 123-127. doi: 10.1139/gen2012-0183

Nirgude, M., Babu, B. K., Shambhavi, Y., Singh, U. M., Upadhyaya, H. D., and Kumar, A. (2014). Development and molecular characterization of genic 
molecular markers for grain protein and calcium content in finger millet (Eleusine coracana (L.) Gaertn.). Mol. Biol. Rep. 41, 1189-1200. doi: 10.1007/s11033013-2825-7

Nirmalakumari, A., Arulselvi, S., Ganapathy, S., Souframanian, J., Senthil, N., and Devan, P. (2007). Gamma ray induced variation for lodging resistance and its associated characters in little millet (Panicum sumatrense Roth Ex-roem and schult). Madras Agric. J. 94, 151-155.

Nirmalakumari, A., Salini, K., and Veerabadhiran, P. (2010). Morphological characterization and evaluation of little millet (Panicum sumatrense Roth ex. Roem. and Schultz) germplasm. Electron. J. Plant Breed. 1, 148-155.

Nirmalakumari, A., Sumathi, P., Joel, A. J., Kumaravadivel, N., Senthil, N., Devan, $\mathrm{P}$., et al. (2008). A high yielding and early maturing panivaragu variety CO (PV) 5. Madras Agric. J. 95, 1-6.

Nishizawa, N., and Fudamoto, Y. (1995). The elevation of plasma concentration of high-density lipoprotein cholesterol in mice fed with protein from proso millet. Biosci. Biotechnol. Biochem. 52, 333-335. doi: 10.1271/bbb.59.333

Nishizawa, N., Sato, D., Ito, Y., Nagasawa, T., Hatakeyama, Y., Choi, M. R., et al. (2002). Effects of dietary protein of proso millet on liver injury induced by D-galactosamine in rats. Biosci. Biotechnol. Biochem. 66, 92-96. doi: 10.1271/bbb.66.92

Nishizawa, N., Togawa, T., Park, K.-O., Sato, D., Miyakoshi, Y., Inagaki, K., et al. (2009). Dietary Japanese millet protein ameliorates plasma levels of adiponectin, glucose, and lipids in type 2 diabetic mice. Biosci. Biotechnol. Biochem. 73, 351-360. doi: 10.1271/bbb.80589

Nozawa, S., Takahashi, M., Nakai, H., and Sato, Y.-I. (2006). Difference in SSR variations between Japanese barnyard millet (Echinochloa esculenta) and its wild relative E. crus-galli. Breed. Sci. 56, 335-340. doi: 10.1270/jsbbs.56.335

Ogie-Odia, E. A., Mokwenye, A. I., Kekere, O., and Timothy, O. (2010). Comparative vegetative and foliar epidermal features of three Paspalum L. species in Edostate, Nigeria. Ozean J. Appl. Sci. 3, 29-38.

Pandey, G., Misra, G., Kumari, K., Gupta, S., Parida, S. K., Chattopadhyay, D., et al. (2013). Genome-wide development and use of microsatellite markers for largescale genotyping applications in foxtail millet (Setaria italica (L.)). DNA Res. 20, 197-207. doi: 10.1093/dnares/dst002

Parani, M., Rajesh, K., Lakshmi, M., Parducci, L., Szmidt, A. E., and Parida, A. (2001). Species identification in seven small millet species using polymerase chain reaction - restriction fragment length polymorphism of trnS-psbC gene region. Genome 44, 495-499. doi: 10.1139/g01-023

Park, K.-O., Ito, Y., Nagasawa, T., Choi, M.-R., and Nishizawa, N. (2014). Effects of dietary Korean proso-millet protein on plasma adiponectin, HDL cholesterol, insulin levels, and gene expression in obese type 2 diabetic mice. Biosci. Biotechnol. Biochem. 72, 2918-2925. doi: 10.1271/bbb.80395

Peterson, D. E., and Nalewaja, J. D. (1992). Environment influences green foxtail (Setaria viridis) competition with wheat (Triticum aestivum). Weed Technol. 6, 607-610.

Plaza-Wüthrich, S., and Tadele, Z. (2012). Millet improvement through regeneration and transformation. Biotechnol. Mol. Biol. Rev. 7, 48-61. doi: 10.5897/BMBR12.001

Pradeep, S. R., and Guha, M. (2011). Effect of processing methods on the nutraceutical and antioxidant properties of little millet (Panicum sumatrense) extracts. Food Chem. 126, 1643-1647. doi: 10.1016/j.foodchem.2010.12.047

Pradhan, A., Thakur, A., Patel, S., and Mishra, N. (2011). Effect of different nitrogen levels on kodo and finger millet under rainfed conditions. Res. J. Agric. Sci. 2, 136-138.

Puranik, S., Jha, S., Srivastava, P. S., Sreenivasulu, N., and Prasad, M. (2011). Comparative transcriptome analysis of contrasting foxtail millet cultivars in response to short-term salinity stress. J. Plant Physiol. 168, 280-287. doi: 10.1016/j.jplph.2010.07.005

Qi, X., Xie, S., Liu, Y., Yi, F., and Yu, J. (2013). Genome-wide annotation of genes and noncoding RNAs of foxtail millet in response to simulated drought stress by deep sequencing. Plant Mol. Biol. 83, 459-473. doi: 10.1007/s11103-013-0104-6

Qin, F. F., Zhao, Q., Ao, G. M., and Yu, J. J. (2008). Co-suppression of Si401, a maize pollen specific $Z m 401$ homologous gene, results in aberrant anther development in foxtail millet. Euphytica 163, 103-111. doi: 10.1007/s10681007-9610-4

Rahman, H., Jagadeeshselvam, N., Valarmathi, R., Sachin, B., Sasikala, R., Senthil, N., et al. (2014). Transcriptome analysis of salinity responsiveness in contrasting genotypes of finger millet (Eleusine coracana L.) through RNAsequencing. Plant Mol. Biol. 85, 485-503. doi: 10.1007/s11103-014-0199-4

Rajput, S. G., Plyler-harveson, T., and Santra, D. K. (2014). Development and characterization of SSR markers in proso millet based on switchgrass genomics. Am. J. Plant Sci. 5, 175-186. doi: 10.4236/ajps.2014.51023

Ramegowda, V., Senthil-Kumar, M., Nataraja, K. N., Reddy, M. K., Mysore, K. S., and Udayakumar, M. (2012). Expression of a finger millet transcription factor, EcNAC1, in tobacco confers abiotic stress-tolerance. PLoS ONE 7:e40397. doi: 10.1371/journal.pone.0040397

Ramegowda, Y., Venkategowda, R., Jagadish, P., Govind, G., Hanumanthareddy, R.-R., Makarla, U., et al. (2013). Expression of a rice Zn transporter, OsZIP1, increases $\mathrm{Zn}$ concentration in tobacco and finger millet transgenic plants. Plant Biotechnol. Rep. 7, 309-319. doi: 10.1007/s11816-012-0264-x

Rao, B. L., and Husain, A. (1985). Presence of cyclopiazonic acid in kodo millet (Paspalum scrobiculatum) causing "kodua poisoning" in man and its production by associated fungi. Mycopathologia 89, 177-180. doi: 10.1007/BF004 47028

Reddy, I. N. B. L., Reddy, D. S., Narasu, M. L., and Sivaramakrishnan, S. (2011). Characterization of disease resistance gene homologues isolated from finger millet (Eleusine coracana L. Gaertn). Mol. Breed. 27, 315-328. doi: 10.1007/s11032-010-9433-1

Reddy, V. G., Upadhyaya, H. D., and Gowda, C. L. L. (2007). Morphological characterization of world's proso millet germplasm. SAT J. 3, 1-4.

Rengalakshmi, R. (2005). Folk biological classification of minor millet species in Kolli hills, India. BioOne 25, 59-70. doi: 10.2993/02780771(2005)25[59:FBCOMM]2.0.CO;2

Rose, D. J., and Santra, D. K. (2013). Proso millet (Panicum miliaceum L.) fermentation for fuel ethanol production. Ind. Crops Prod. 43, 602-605. doi: 10.1016/j.indcrop.2012.08.010

Sabir, P., Ashraf, M., and Akram, N. A. (2011). Accession variation for salt tolerance in proso millet (Panicum miliaceum L.) using leaf proline content and activities of some key antioxidant enzymes. J. Agron. Crop Sci. 197, 340-347. doi: 10.1111/j.1439-037X.2011.00471.x

Salimath, S. S., Oliveira, A. C. D., Godwin, I. D., and Bennetzen, J. L. (1995). Assessment of genome origins and genetic diversity in the genus Eleusine with DNA markers. Genome 38, 757-763. doi: 10.1139/g95-096

Schontz, D., and Rether, B. (1999). Genetic variability in foxtail millet, Setaria italica (L.) P. Beauv.: identification and classification of lines with RAPD markers. Plant Breed. 118, 190-192. doi: 10.1046/j.1439-0523.1999.118002190.x

Seghatoleslami, M. J., Kafi, M., and Majidi, E. (2008). Effect of drought stress at different growth stages on yield and water use efficiency of five proso millet (Panicum milaceum L.) genotypes. Pakistan J. Bot. 40, 1427-1432.

Sentoku, N., Taniguchi, M., Sugiyama, T., Ishimaru, K., Ohsugi, R., Takaiwa, F., et al. (2000). Analysis of the transgenic tobacco plants expressing Panicum miliaceum aspartate aminotransferase genes. Plant Cell Rep. 19, 598-603. doi: 10.1007/s002990050779

Sharma, M., Kothari-Chajer, A., Jagga-Chugh, S., and Kothari, S. L. (2011). Factors influencing Agrobacterium tumefaciens-mediated genetic transformation of Eleusine coracana (L.) Gaertn. Plant Cell Tissue Organ Cult. 105, 93-104. doi: 10.1007/s11240-010-9846-x

Singh, U. M., Chandra, M., Shankhdhar, S. C., and Kumar, A. (2014). Transcriptome wide identification and validation of calcium sensor gene family in the developing spikes of finger millet genotypes for elucidating its role in grain calcium accumulation. PLOS ONE 9:e103963. doi: 10.1371/journal.pone. 0103963

Sivakumar, S., Franco, O. L., Thayumanavan, B., Murad, A. M., Manickam, A., Mohan, M., et al. (2006a). Cloning and structural analysis of an Indian little millet (Panicum sumatrense) zein-like storage protein: Implications for molecular assembly. Biochemistry 71, 1183-1191. doi: 10.1134/S0006297906110034

Sivakumar, S., Mohan, M., Franco, O. L., and Thayumanavan, B. (2006b). Inhibition of insect pest $\alpha$-amylases by little and finger millet inhibitors. Pestic. Biochem. Physiol. 85, 155-160. doi: 10.1016/j.pestbp.2005.11.008

Smith, P. M. (1977). "Minor crops," in Evolution of Crop Plants, ed N. W. Simmonds (London; New York: Longman), 301-324.

Subrahmanyam, D., and Rathore, V. S. (1999). Variation in photosynthetic traits in barnyard millet (Echinocloa frumentaceae) genotypes. J. Agron. Crop Sci. 183, 199-203. doi: 10.1046/j.1439-037x.1999.00341.x 
Subramanian, A., Nirmalakumari, A., and Veerabadhiran, P. (2010). Trait based selection of superior kodo millet (Paspalum scrobiculatum L.) genotypes. Electron. J. Plant Breed. 1, 852-855.

Sudhakar, C., Veeranagamallaiah, G., Nareshkumar, A., Sudhakarbabu, O., Sivakumar, M., Pandurangaiah, M., et al. (2015). Polyamine metabolism influences antioxidant defense mechanism in foxtail millet (Setaria italica L.) cultivars with different salinity tolerance. Plant Cell Rep. 34, 141-156. doi: 10.1007/s00299-014-1695-3

Taniguchi, M., Kobe, A., Kato, M., and Sugiyama, T. (1995). Aspartate aminotransferase isozymes in Panicum miliaceum L., an NAD-malic enzyme-type C4 plant: comparison of enzymatic properties, primary structures, and expression patterns. Arch. Biochem. Biophys. 318, 295-306. doi: 10.1006/abbi.1995.1233

Taniguchi, M., and Sugiyama, T. (1996). Isolation, characterization and expression of cDNA clones encoding a mitochondrial malate translocator from Panicum miliaceum L. Plant Mol. Biol. 30, 51-64. doi: 10.1007/BF00017802

Taniguchi, M., and Sugiyama, T. (1997). The expression of 2-oxoglutarate/malate translocator in the bundle-sheath mitochondria of Panicum miliaceum, a NADmalic enzyme-type C4 plant, is regulated by light and development. Plant Physiol. 114, 285-293.

Tester, M., and Langridge, P. (2010). Breeding technologies to increase crop production in a changing world. Science 327, 818-822. doi: 10.1126/science.1183700

Tsehaye, Y., Berg, T., Tsegaye, B., and Tanto, T. (2006). Farmers' management of finger millet (Eleusine coracana L.) diversity in Tigray, Ethiopia and implications for on-farm conservation. Biodivers. Conserv. 15, 4289-4308. doi: 10.1007/s10531-005-3581-3

Ugare, R., Chimmad, B., Naik, R., Bharati, P., and Itagi, S. (2014). Glycemic index and significance of barnyard millet (Echinochloa frumentacae) in type II diabetics. J. Food Sci. Technol. 51, 392-395. doi: 10.1007/s13197-011-0516-8

Uma, S., Prasad, T. G., and Kumar, M. U. (1995). Genetic variability in recovery growth and synthesis of stress proteins in response to polyethylene glycol and salt stress in finger millet. Ann. Bot. 76, 43-49. doi: 10.1006/anbo.1995.1076

Upadhyaya, H. D., Dwivedi, S. L., Singh, S. K., Singh, S., Vetriventhan, M., and Sharma, S. (2014). Forming core collections in barnyard, kodo, and little millets using morphoagronomic descriptors. Crop Sci. 54, 1-10. doi: 10.2135/cropsci2014.03.0221

Upadhyaya, H. D., Pundir, R. P. S., Gowda, C. L. L., Gopal Reddy, V., and Singh, S. (2008). Establishing a core collection of foxtail millet to enhance the utilization of germplasm of an underutilized crop. Plant Genet. Res. 7, 177-184. doi: $10.1017 /$ S1479262108178042

Upadhyaya, H. D., Ravishankar, C. R., Narasimhudu, Y., Sarma, N. D. R. K., Singh, S. K., Varshney, S. K., et al. (2011). Identification of trait-specific germplasm and developing a mini core collection for efficient use of foxtail millet genetic resources in crop improvement. Field Crop. Res. 124, 459-467. doi: 10.1016/j.fcr.2011.08.004

Usha, B., Krishna Veni, G., Muni Kumar, D., and Hemalatha, K. P. J. (2011). Partial characterization of $\alpha$-amylase from germinating little millets (Panicum sumatrense). J. Phytol. 3, 1-8.

Vadivoo, A. S., Joseph, R., and Ganesan, N. M. (1998). Genetic variability and diversity for protein and calcium contents in finger millet (Eleusine coracana (L.) Gaertn) in relation to grain color. Plant Foods Hum. Nutr. 52, 353-364. doi: $10.1023 / \mathrm{A}: 1008074002390$

Van, K., Onoda, S., Kim, M. Y., Kim, K. D., and Lee, S. H. (2008). Allelic variation of the Waxy gene in foxtail millet (Setaria italica (L.) P. Beauv.) by single nucleotide polymorphisms. Mol. Genet. Genomics 279, 255-266. doi: $10.1007 / \mathrm{s} 00438-007-0310-5$

Veeranagamallaiah, G., Jyothsnakumari, G., Thippeswamy, M., Reddy, P. C. O., Surabhi, G.-K., Sriranganayakulu, G., et al. (2008). Proteomic analysis of salt stress responses in foxtail millet (Setaria italica L. cv. Prasad) seedlings. Plant Sci. 175, 631-641. doi: 10.1016/j.plantsci.2008.06.017

Wang, C., Jia, G., Zhi, H., Niu, Z., Chai, Y., Li, W., et al. (2012). Genetic diversity and population structure of Chinese foxtail millet [Setaria italica (L.) Beauv.] landraces. G3 2, 769-777. doi: 10.1534/g3.112.002907
Wang, J. C., Hu, J., Xu, H. M., and Zhang, S. (2007). A strategy on constructing core collections by least distance stepwise sampling. Theor. Appl. Genet. 115, 1-8. doi: 10.1007/s00122-007-0533-1

Wang, M., Pan, Y., Li, C., Liu, C., Zhao, Q., Ao, G.-M., et al. (2011). Culturing of immature inflorescences and Agrobacterium-mediated transformation of foxtail millet (Setaria italica). Afr. J. Biotechnol. 10, 16466-16479. doi: $10.5897 /$ ajb10.2330

Wang, T., and Darmency, H. (1997). Inheritance of sethoxydim resistance in foxtail millet, Setaria italica (L.). Euphytica 94, 69-73. doi: 10.1023/A:1002989725995

Wang, T., Fleury, A., Ma, J., and Darmency, H. (1996). Genetic control of dinitroaniline resistance in foxtail millet (Setaria italica). J. Hered. 87, 423-4266. doi: 10.1093/oxfordjournals.jhered.a023031

Wang, Z. M., Devos, K. M., Liu, C. J., Wang, R. Q., and Gale, M. D. (1998). Construction of RFLP-based maps of foxtail millet, Setaria italica (L.) P. Beauv. Theor. Appl. Genet. 96, 31-36. doi: 10.1007/s001220050705

Wanous, M. K. (1990). Origin, taxonomy and ploidy of the millets and minor cereals. Plant Var. Seeds 3, 99-112.

Wu, Y., Du, J., Wang, X., Fang, X., Shan, W., and Liang, Z. (2012). Computational prediction and experimental verification of miRNAs in Panicum miliaceum L. Sci. China 55, 807-817. doi: 10.1007/s11427-012-4367-y

Yabuno, T. (1962). Cytotaxonomic studies on the two cultivated species and the wild relatives in the genus Echinochloa. Cytologia 27, 296-305. doi: 10.1508/cytologia.27.296

Yabuno, T. (1987). Japanese barnyard millet (Echinochloa utilis, Poaceae) in Japan. Econ. Bot. 41, 484-493. doi: 10.1007/BF02908141

Yadav, C. B., Muthamilarasan, M., Pandey, G., Khan, Y., and Prasad, M. (2014a). Development of novel microRNA-based genetic markers in foxtail millet for genotyping applications in related grass species. Mol. Breed. 34, 2219-2224. doi: 10.1007/s11032-014-0137-9

Yadav, S., Gaur, V. S., Jaiswal, J. P., and Kumar, A. (2014b). Simple sequence repeat (SSR) analysis in relation to calcium transport and signaling genes reveals transferability among grasses and a conserved behavior within finger millet genotypes. Plant Syst. Evol. 300, 1561-1568. doi: 10.1007/s00606-014-0982-3

Yamaguchi, H., Utano, A. Y. A., Yasuda, K., Yano, A., and Soejima, A. (2005). A molecular phylogeny of wild and cultivated Echinochloa in East Asia inferred from non-coding region sequences of trn T-L-F. Weed Biol. Manag. 5, 210-218. doi: 10.1111/j.1445-6664.2005.00185.x

Yang, X., Wan, Z., Perry, L., Lu, H., Wang, Q., Zhao, C., et al. (2012). Early millet use in northern China. PNAS 109, 3726-3730. doi: 10.1073/pnas.1115430109

Yang, X., Yu, X.-Y., and Li, Y.-F. (2013). De novo assembly and characterization of the Barnyardgrass (Echinochloa crus-galli) transcriptome using next-generation pyrosequencing. PLoS ONE 8:e69168. doi: 10.1371/journal.pone.0069168

Zhang, G., Liu, X., Quan, Z., Cheng, S., Xu, X., Pan, S., et al. (2012). Genome sequence of foxtail millet (Setaria italica) provides insights into grass evolution and biofuel potential. Nat. Biotechnol. 30, 549-554. doi: 10.1038/nbt.2195

Zhang, L., Liu, R., and Niu, W. (2014). Phytochemical and antiproliferative activity of proso millet. PLoS ONE 9:e104058. doi: 10.1371/journal.pone.0104058

Zhu, X. L., Zhang, L., Chen, Q., Wan, J., and Yang, G. F. (2006). Interactions of aryloxyphenoxypropionic acids with sensitive and resistant acetyl-coenzyme a carboxylase by homology modeling and molecular dynamic simulations. J. Chem. Inf. Model. 46, 1819-1826. doi: 10.1021/ci0600307

Conflict of Interest Statement: The authors declare that the research was conducted in the absence of any commercial or financial relationships that could be construed as a potential conflict of interest.

Copyright (๑) 2015 Goron and Raizada. This is an open-access article distributed under the terms of the Creative Commons Attribution License (CC BY). The use, distribution or reproduction in other forums is permitted, provided the original author(s) or licensor are credited and that the original publication in this journal is cited, in accordance with accepted academic practice. No use, distribution or reproduction is permitted which does not comply with these terms. 